\title{
THE PYROCLASTIC KOMATIITE COMPLEX AT SATTASVAARA IN NORTHERN FINLAND
}

\author{
MATTI SAVERIKKO
}

SAVERIKKO, MATTI, 1985: The pyroclastic komatiite complex at Sattasvaara in northern Finland. Bull. Geol. Soc. Finland 57, Part 1-2, 55-87.

The Sattasvaara komatiite complex is part of an extensive zone of explosive komatiitic volcanism which may have been a significant stage in the Lapponian evolution regarded as Archean. This volcanism took place at the latest $2.43 \mathrm{Ga}$ ago and appears to have been connected with cratonic rifting in the Baltic Shield. The complex was formed by fissure eruptions rather than central-vent eruptions, at the margin of a restricted depositional basin. Effusive, explosive and mixed eruption phases were separated by erosional periods and the komatiitic volcanism was succeeded by mafic effusions and explosive eruptions.

The Sattasvaara complex is composed of interchanging amphibole rocks, or komatiitic basalts, and amphibole-chlorite rocks or (basaltic)komatiites, and encloses minor serpentinitic and peridotitic rocks as terminal komatiite flows and picrite plugs. However, main part of the komatiites has discharged earlier and is present as intercalations in graphitic slate zone beneath the Sattasvaara complex.

The komatiitic rocks were originally co-magmatic according to their gradual rock suite. The komatiitic basalt ( $\mathrm{MgO} 9-18 \mathrm{wt} . \%$ anhydrous basis) shows signs of fractional crystallization of pyroxene and plagioclase, whereas the (basaltic)komatiite ( $\mathrm{MgO} 18-29 \mathrm{wt} . \%$ anhydrous basis) contains pyroxene and olivine phenocrysts and the komatiite $(\mathrm{MgO}>29$ wt. $\%$ anhydrous basis) is olivinepyroxene cumulate both in distinct flows and lower parts of the (basaltic)komatiite flows. The erupting lavas differed physically and discharged in unlike manner: eruptions of the fluid komatiitic basalt were Hawaiian-type and the ones of the viscous (basaltic)komatiite were Strombolian-type. The initial komatiite flows were most fluidal and flowed after the manner of flood eruptions.

Pyroclasticity is associated with the (basaltic)komatiite that is dominantly fragmentary, consisting of lithic, vitric and crystal ejecta; subordinate lava flows are largely block lavas. The voluminous explosive eruptions appear to have been magmatic in origin. Also, a minor pyroclastic breccia is formed by the komatiitic basalt that is usually present in massive or pillowed lava flows; these exceptional volcanic explosions have possibly caused by hydromagmatic eruptions.

The komatiitic rocks may have been source of the gold contained in chromian marbles and quartzite-conglomerates nearby the Sattasvaara complex and the komatiitic volcanism seems to have caused iron-manganoferrous emanations in its periphery.

Key words: komatiitic basalt, komatiite, pyroclastic, petrography, chemical analyses, greenstone belt, Archean evolution, central Lapland, Finland, Baltic Shield.

Matti Saverikko: Department of Geology, University of Helsinki, P.O. Box 115, SF-00171 Helsinki 17, Finland. 


\section{Introduction}

The pyroclastic komatiites at Sattasvaara are located in the schist area of central Lapland which is a part of the Precambrian crust of northern Finland (Fig. 1) lying in the Baltic Shield.

The bedrock in Finland is composed of Archean basement complex in the eastern and northern parts of the country and Proterozoic cover in the south and west. Within the basement-gneiss complex there are narrow schist zones in eastern Finland (Simonen 1980) identified as Archean geenstone belts (Gaál et al. 1978, Blais et al. 1979, Hanski 1980, Auvray et al. 1982, Taipale 1983) and high-grade metamorphic supracrustal terrain present as a granu-

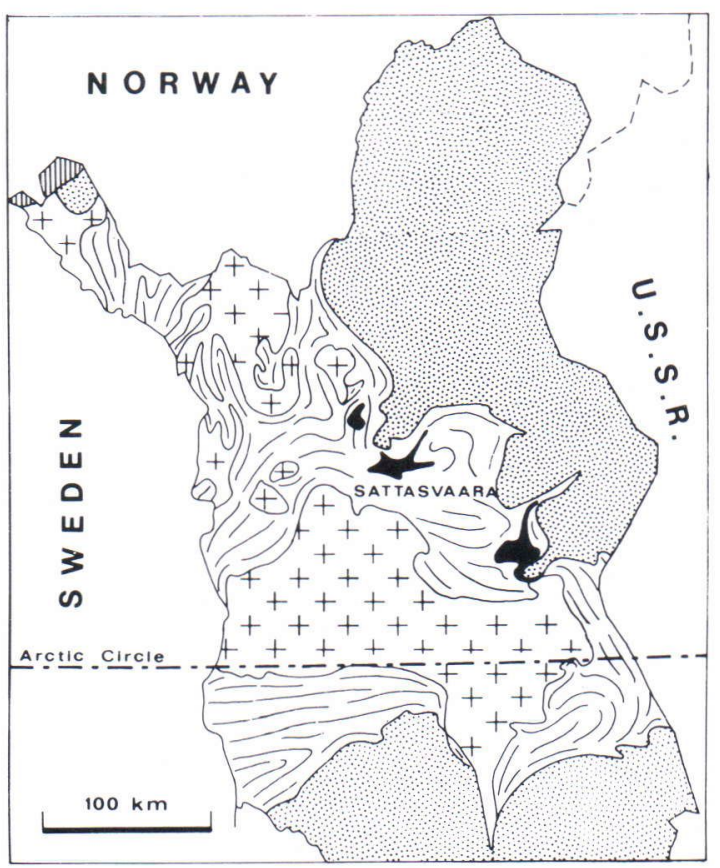

1. Pre-Svecokarellan basement: 2 . E7 Sveco karelian schists: 3 . komatiites: $4 .+$ Sveco

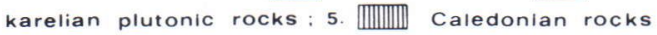

Fig. 1. Location of the Sattasvaara komatiite complex and other pyroclastic komatiites (Kallio et al. 1980, Saserikko 1983) in northern Finland. The lithologic map simplified after Simonen (1980). litic arc in northern Finland (Meriläinen 1976, Hörmann et al. 1980). The Proterozoic schists, heavily disrupted by synorogenic and postorogenic plutons, which are separated by a firstorder unconformity from the basement, make up the Svecokarelian fold belt (Simonen 1980). Its lower schists form Karelian successions and their deposition has begun at 2.5 Ga ago (Meriläinen 1980).

The schist area of central Lapland has been connected with the Karelian schist belt (Simonen 1960, 1971, 1980) but Silvennoinen et. al. (1980) manifest that most schist in central Lapland are Archean in age. Noteworthily, Sederholm (1932) and Mikkola (1941) already thought them to correspond lithologically to those of the Archean greenstone belts in eastern Finland; only the upper rocks are regarded as Karelian in age.

Mikkola (1941) and his co-worker Sahama (1945) divided the schist area of central Lapland into two lithostratigraphic units: the Lapponian schists lying discordantly on the basement and the Kumpu-Oraniemi conglomeratic quartzites resting unconformably on the Lapponian schists. Mikkola (1941) considered the upper succession to consist of Kumpu conglomeratic quartzite suite and Oraniemi arkose-quartzite mica-schist suite. But since the latter stratigraphically belongs under the Lapponian schists (Saverikko 1977, 1978), the supracrustal rocks are lithostratigraphically divisible into the Lapponian sequence of Archean age and the Kumpu suite belonging under the Karelian successions.

The Lapponian metavolcanic rocks appear gathered into spatially isolated greenstone belts (Gaál et al. 1978) containing komatiitic rocks (Sarapää 1980, Kröner et al. 1981, Saverikko 1983, Räsänen 1984).

\section{Geological setting}

Amphibole-chlorite rocks in the Sattasvaara area have been established by Mutanen (1976) to be komatiitic greenstones. These rocks be- 


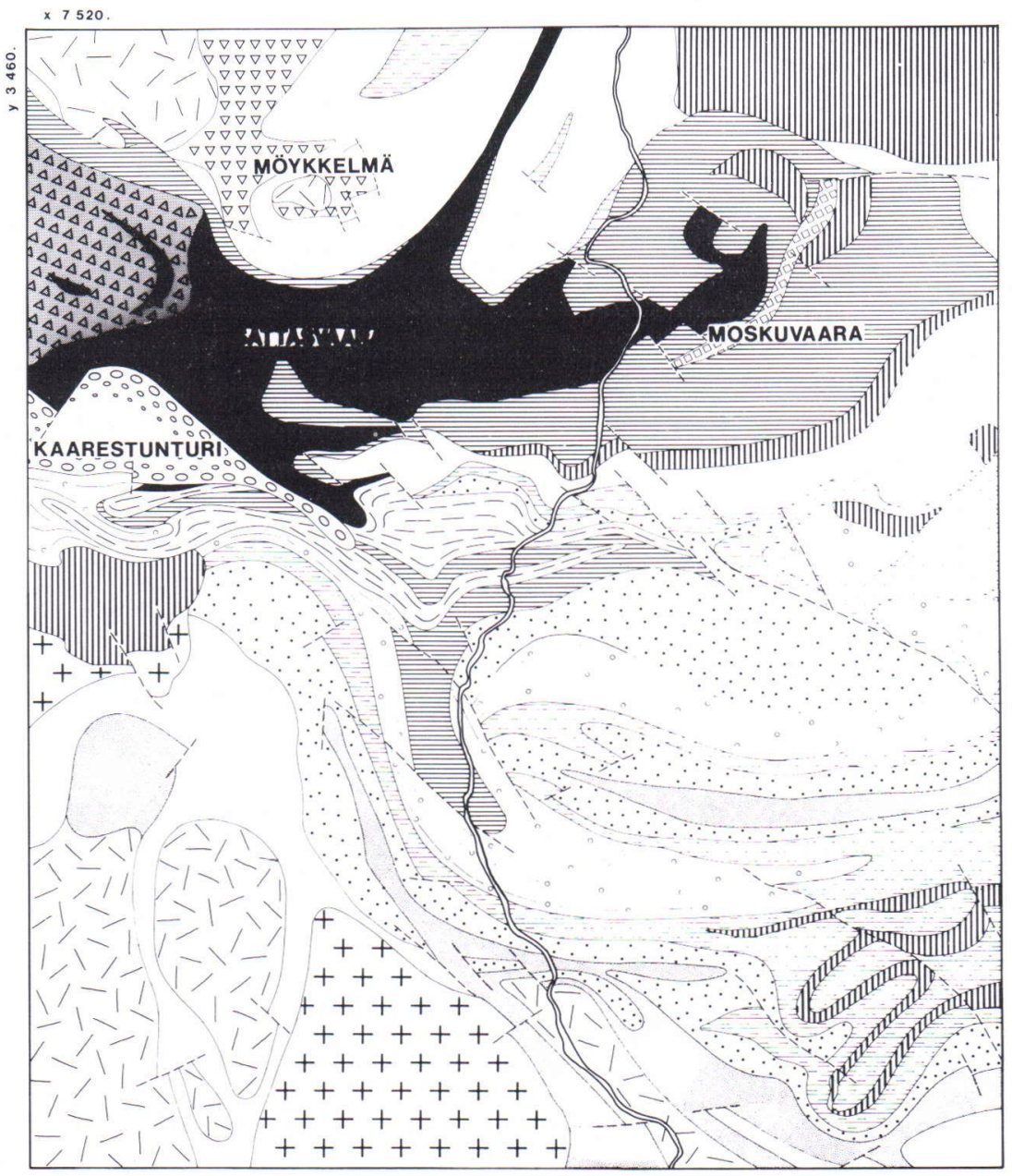

GENERAL GEOLOGICAL MAP

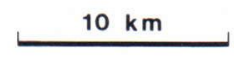

Po을 Conglomeratic quartzite

$\triangle \Delta \Delta$ Greenstone and carbo-

Komatiite complex

Eraphitic slate zone
$E$ Amphibolite

Sericite quartzite

Metapelite

$\because \because$ Orakoski quartzite

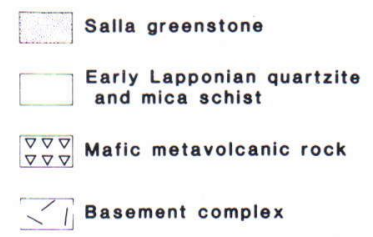

+ Granite

[IIIII Gabbro or peridotite-gabbro

Fig. 2. Geological sketch map of the Sattasvaara area. 


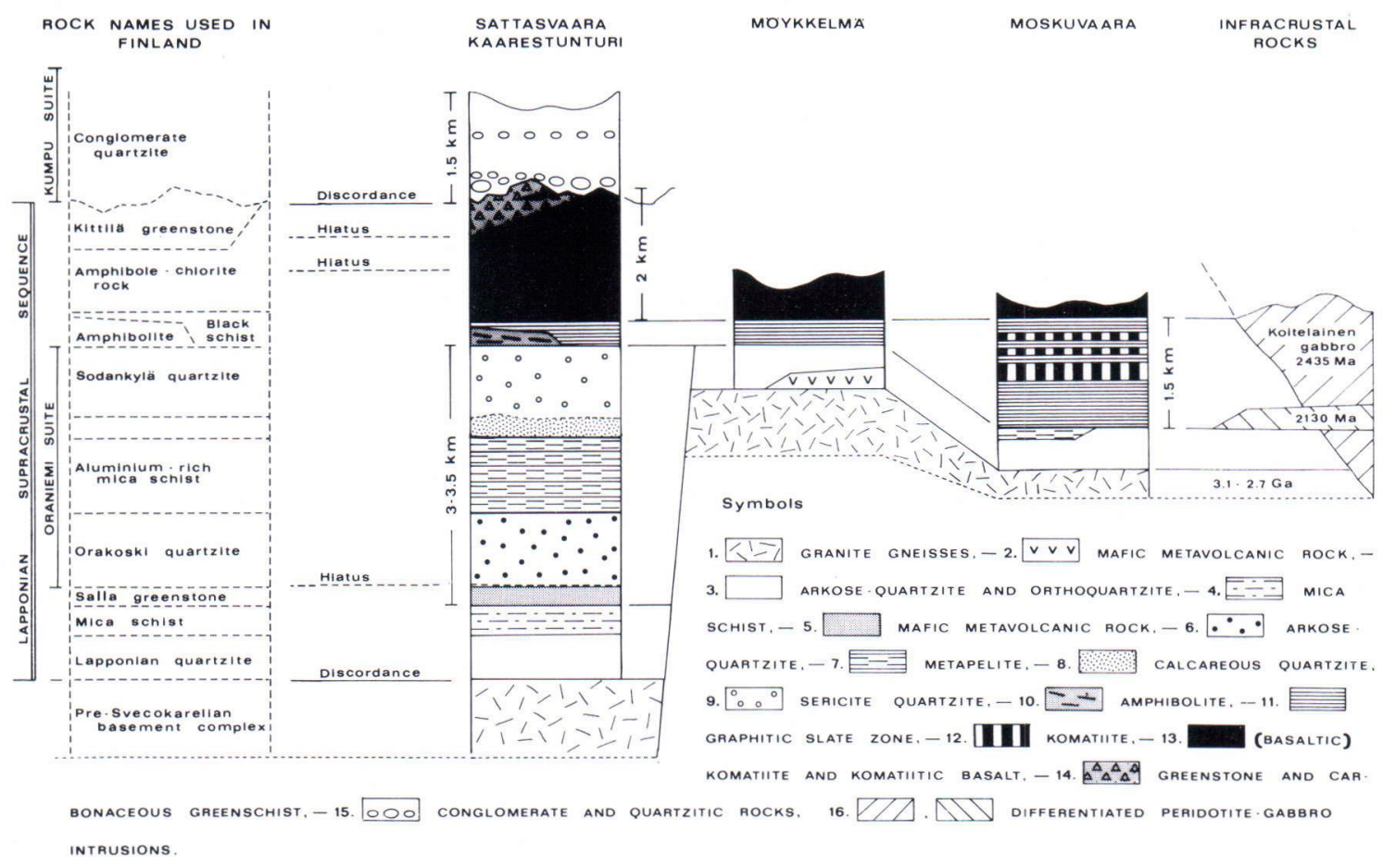

Fig. 3. Stratigraphic position of the Sattasvaara komatiite complex that is composed of (basaltic) komatiites and komatiitic basalts.

long under Kittilä greenstone complex (Paakkola 1971, Rastas 1980) which is the uppermost unit of the Lapponian supracrustal sequence (Mikkola 1941, Rastas 1980). The sedimentary association underneath differs on the south and north sides of the Sattasvaara komatiite complex, as the Oraniemi suite practically disappears in the northern and eastern stratigraphic records at Möykkelmä and Moskuvaara (Figs. $2,3)$.

The basement complex is structurally complicated, consisting of orthogneisses of granodioritic, granitic, trondhjemitic, tonalitic and dioritic composition (Isomaa 1978, Kallio et al. 1980, Kröner et al. 1981, Tyrväinen 1983); paragneiss inclusions are mica gneiss and conglomeratic arkose-gneiss (Isomaa 1978, Saverikko 1978). One tonalitic gneiss dome has been dated as $3.1 \mathrm{Ga}$ in age but the basement complex was deformed and isotopically reset $2.7 \mathrm{Ga}$ ago, before greenstone deposition (Kröner et al. 1981). The complex is covered with an ancient residue that grades into basal arkose and Lapponian quartzite, or arkose-quartzite with quartz-arenitic laminae and sericitic interlayers (Räsänen 1977, Tyrväinen 1983).

On the south side of the komatiitic complex, these schists are partially covered with a greenstone (Haimi 1977, Mielikäinen 1979, Tyrväinen 1979) described by Saverikko and Manninen (1981) as Salla greenstone complex. The Oraniemi suite overlies this complex, and is made up of Orakoski quartzite, a metapelite and a sericite quartzite with arkosic zones (Saverikko 1977, Rask 1978).

A heterogeneous graphitic slate zone lies on the Oraniemi suite and other Lapponian schists mentioned above (Saverikko 1978). The slates vary from phyllite to black slate (Mikkola 1941), and the uppermost stratum in places is 
greywacke (Papunen et al. 1977) with graphitebearing matrix and minor conglomerates. The slates include dolomite, calc-silicate slate, chert, mafic tuff or tuffite, adinole and felsic metavolcanic rock (Mikkola 1941, Tyrväinen 1983, Pulkkinen et al. 1983).

The graphitic slate zone contains also serpentinites and peridotites, which are chemically similar to komatiites but, lacking volcanic structures, have been regarded as sills rather than effusives (Mutanen 1976, Papunen et al. 1979). However, Mikkola (1941) has described chloritic vesicles in one serpentinite.

The komatiitic rocks upon the graphitic slate zone are agglomerates, lavas and tuffs, and these amphibole-chlorite rocks are associated with mafic metavolcanic rocks such as amphibole rock, amphibole-plagioclase rock and spilite (Mikkola 1941, Paakkola 1971, Tyrväinen 1983). The Kittilä greenstone complex contains also distinct interlayers of clastic and chemical metasediments, viz. greenschists of tuffaceous, argillaceous and arenaceous origin with conglomerates, jaspers and jaspilites, carbonaceous schists, sulphide schists and manganosiderite schists (Paakkola 1971, Räsänen 1977, Gehör 1982).

The uppermost supracrustal unit in the study area is a local relic of the Kumpu suite, made up of conglomerates and quartzites, of strongly varying composition (Räsänen 1977).

Plutonic activity has been very weak in the Sattasvaara area, evident only in a few intrusions around the komatiite complex. Most are differentiated peridotite-gabbro sills and the most important layered intrusion is the Koitelainen gabbro complex (2435 Ma in age) appearing as a laccolithic sheet (Puustinen 1977) and containing inclusions of komatiitic rocks (T. Mutanen, pers. commun. 1983).

Except for the Oraniemi suite the supracrustal sequence in the Sattasvaara area is comparable to sequences in the Salla-Jauratsi greenstone belt which also contains uniform komatiitic rocks (Saverikko 1983). Thus, the Kitti- lä and Salla-Jauratsi greenstone belts are made up partially of the same metavolcanic units, while their essential parts, the Kittilä and Salla greenstone complexes, are separated by the Oraniemi suite, the amphibolite and the graphitic slate zone.

The pyroclastic komatiite complex at Sattasvaara is located in an extensive arc-shaped zone of explosive komatiitic volcanism in the Baltic Shield (Saverikko et al. 1985).

\section{Petrographic features}

The Sattasvaara komatiite complex is visible as a prominently exposed hilly area with volcanic structures prevailing in outcrops. These volcanic structures and the primary microscopic textures are described here according to the nomenclature and classifications of Fisher (1961, 1966) and Cook (1965).

The serpentinitic and peridotitic rocks present in extensive sheets beneath the complex are described briefly together with minor uniform lava flows in the complex. The greenstone and greenschists, intertonguing with the komatiite complex will be mentioned as well.

\section{The Sattasvaara komatiite complex}

The komatiite complex is upfacing, overlying the graphitic slate zone and partially covered by the greenstone with carbonaceous greenschists and the conglomeratic quartzite (Fig. 4). The complex itself consists of plagioclase-bearing amphibole rock and amphibolechlorite rock, or komatiitic basalt and (basaltic) komatiite, respectively (see p. 75). The body of the complex is amphibole rock, while the amphibole-chlorite rock is present in at least two separate exposure: an older interlayer within the amphibole rock and the uppermost layer which is cut by the erosion surface (Fig. 5).

The amphibole-chlorite rock in the uppermost layer forms a relict cinder cone at Sattas- 


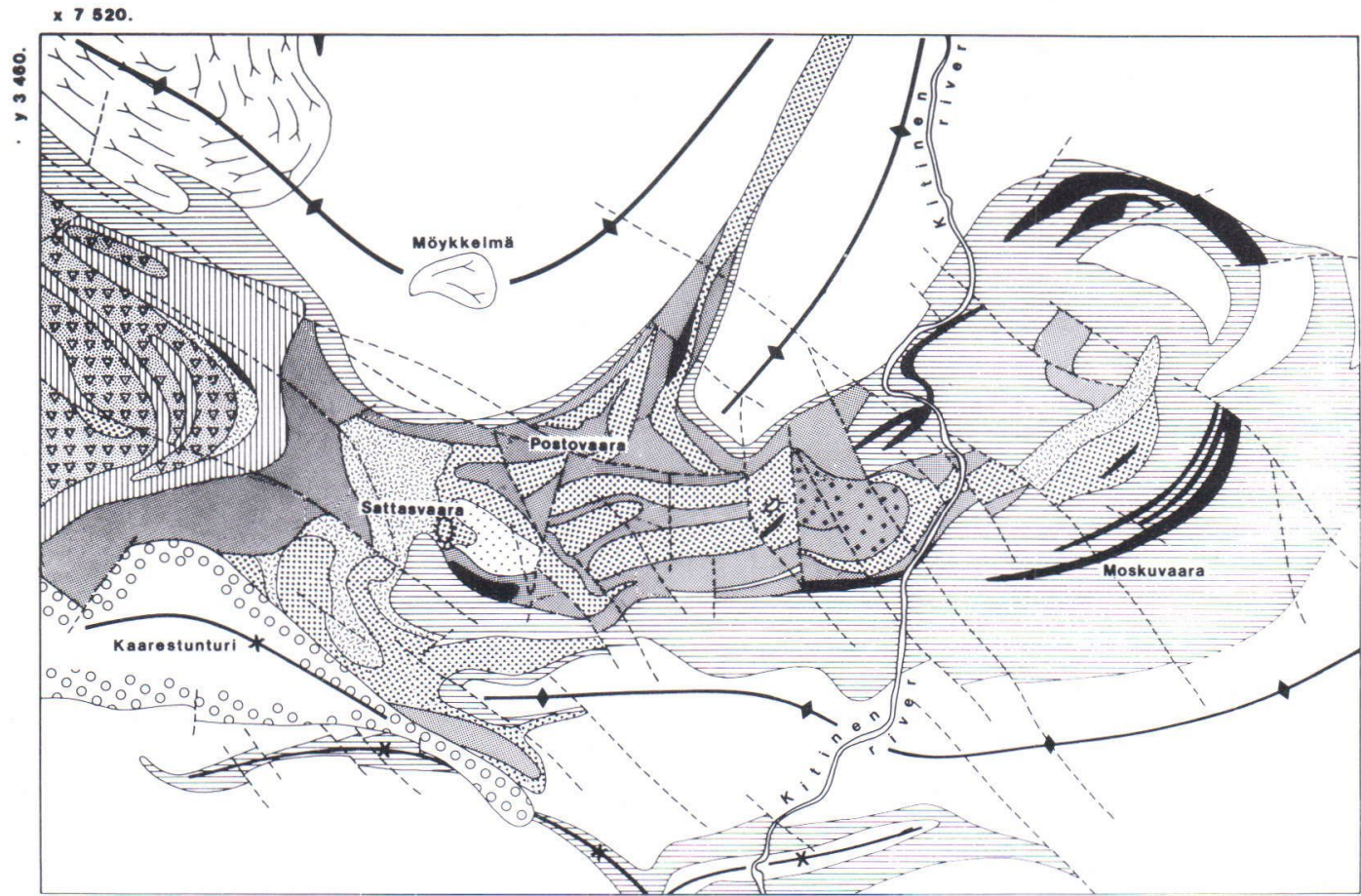

\section{GEOLOGICAL MAP}

of

the Sattasvaara komatiite complex

(Basaltic)komatiite

Tuff and lapilli tuff

Lapillistone, Cinder cone

Lava

Komatiitic basalt

$\because:-$ Pyroclastic breccia

Lava

\section{Conglomeratic quartzite}

$\nabla \nabla \nabla$
$\nabla \nabla \nabla$ Greenstone, Volcanic neck

IIIIIII Carbonaceous greenschists

Komatiite

琶 Graphitic slate zone

Other rocks

Basement complex

Inferred fault

Anticline

Syncline

Fig. 4. Geological map of the Sattasvaara komatiite complex. 


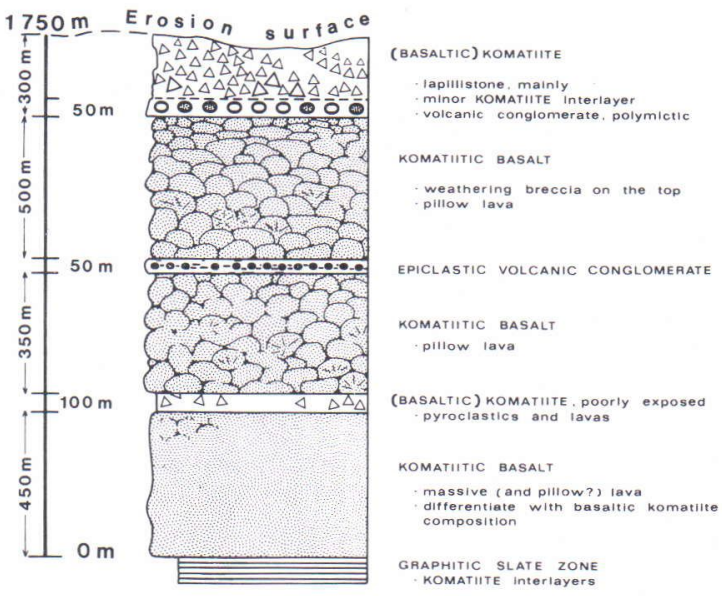

Fig. 5. Internal stratigraphic structure of the Sattasvaara komatiite complex. Location of the geologic section is marked with the line $\mathrm{A}-\mathrm{B}$ on the map in Figure 7.

vaara and the lava flows around are penetrated by a volcanic neck $(\varnothing 10-30 \mathrm{~m})$ filled with amphibole-chlorite rock rich in serpentine (Fig. 6). In all probability other komatiitic feeders exist as well; for there is an isolated lava-flow pile of amphibole-chlorite rock situated far away from the cinder cone, in the easternmost part of the complex.

The komatiite complex is disrupted by mafic volcanic conduits encountered as two necks $(\varnothing$ $0.3 \mathrm{~km}, 10-50 \mathrm{~m}$ ) and a swarm of lava dikes cutting the cinder cone. A serpentinite exposure about $1 \mathrm{~km}$ southeast of Sattasvaara, which encloses magnetite and asbestos veins cutting as well the surrounding komatiitic rocks, is picrite plug or komatiite neck. Small ophite sheets or dikes lie on a line striking eastward from Sattasvaara; they may be associated with the lithologically similar sheet on the east side of the complex.

\section{Komatiitic basalt}

The amphibole rock, or komatiitic basalt, is composed of three distinct units: massive lava flows, pillow lavas and pyroclastic rocks. The pillow lavas lie on the southern side of the line striking estward from Sattasvaara and they are interrupted by erosional interfaces shown as a
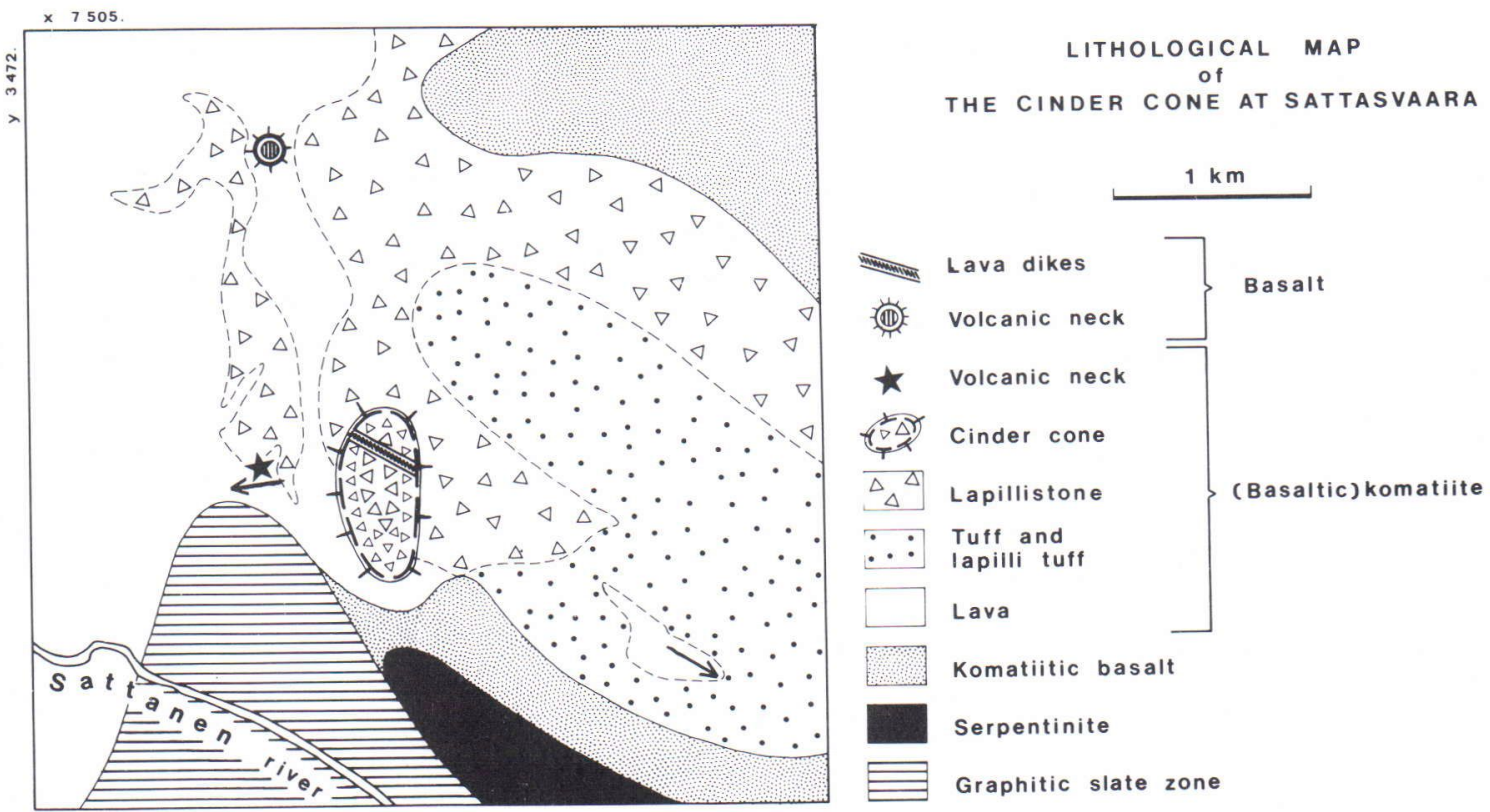

Fig. 6. Lithologic surroundings of the cinder cone at the Sattasvaara hill. Arrows show flow direction recognized on the basis of platy flow structures or flow morphology. 


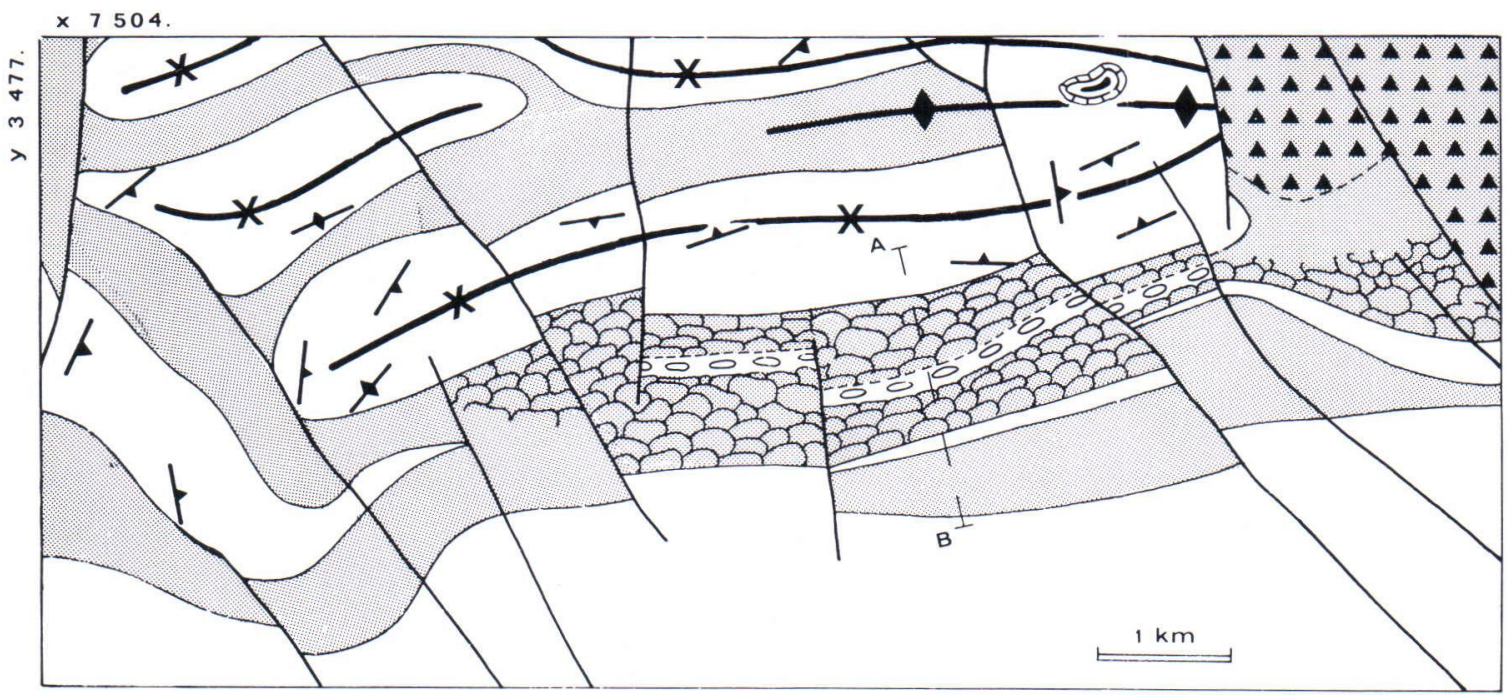

Komatitic basalt Massive lava. A A A Pyroclastic rock: 000 Epiclastic volcanic conglomerate: Mafic volcanic neck:

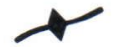

Anticline

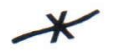

Syncline:

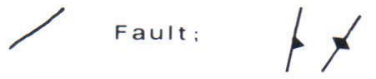

Foliation

Fig. 7. Distribution of the pillow lavas in the komatiitic basalt. The line A-B locates the stratigraphic section in Figure 5 .

weathering breccia and conglomerates (Fig. 7). The pyroclastic rocks are concentrated in the eastern part of the exposure but scattered pyroclasts are found around a pile of lava driblets in spatter cone-like form, about $5 \mathrm{~km}$ northwest of Sattasvaara.

The massive lavas enclose a wide spread stratiform horizon of carbonate-chlorite-talc rock which may have lithologic similarity to the Archean host rock of the gold and antimony mineralization in South Africa, described by Pearton (1982). A genetic relationship to the gold-bearing chromian marbles at Kittilä (Pekkala and Puustinen 1978) is probable, since they appear to lie on the same stratigraphic level, in association with talc-carbonate-chlorite schist.

The komatiitic basalt, exhibiting green weathering and fresh surfaces, is aphanitic to medium-grained amphibole rock having plagioclase as disseminations or as laminae contorted by flowage. In the pyroclastic rocks the matrix usually contains plagioclase along with amphibole, and amphibole-plagioclase pyroclasts accompany the amphibolic ejecta. The komatiitic basalt includes disseminated carbonate and in tectonically sheared and brecciated zones magnetite forms coarse grains and breccial filling.

The massive lavas commonly display flow structures slightly or moderately autobrecciated. The subrounded fragments $(\varnothing 0.5-30 \mathrm{~cm})$ are sharply outlined and close fitting and they have chilled margins only rarely. The massive flows enclose spherical and some ragged amygdules ( $\varnothing 0.1-2 \mathrm{~cm}$ ) filled with epidote, feldspath, carbonate or amphibole. Where concentrated, the amygdules appear in planar arrangement and are elongated by flowage. Borders of some flows are almost scoriaceous. Boundaries be- 
tween the flows are sharp and smooth, indicated by differences in shade of colour or degree of fragmentation (Fig. 8).

The spatter cone-like lava formation overlies the massive flows. The absence of radial cracks may indicate that the lava driblets in the accumulation are spatters rather than stretched pillows, and in three-dimensional form in the outcrop they build a distinct cone (Fig. 9) surrounded by the massive flows enclosing scattered pyroclasts.

The lava pillows $(\varnothing 5-100 \mathrm{~cm})$ are spherical, ellipsoidal or flattened with a tail (Fig. 10) and are uniformly accumulated enclosing only a few massive lava-flow pockets several metres in diameter. Chilled skins and polygonal shrinkage

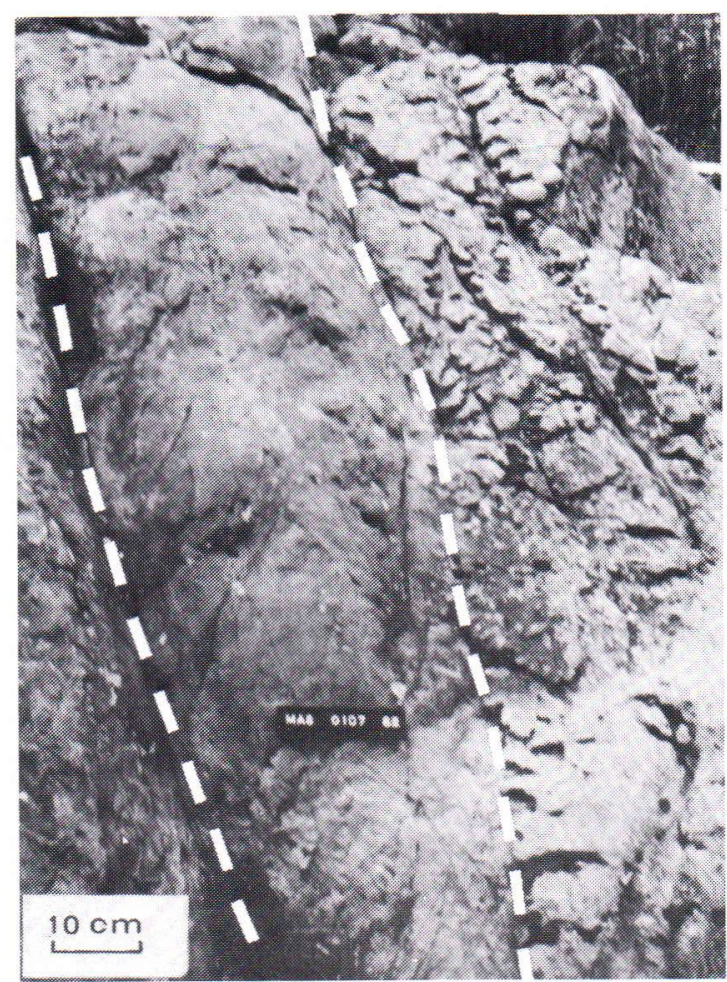

Fig. 8. Three komatiitic basalt flows lie one on top of the other, dipping moderately towards the right. Contacts are marked with dashed lines. The flow on the right is distinctly fragmentary due to the higher viscosity and consequent autobrecciation of this lava. Eastern bank of the Kitinen river. Photo by the author. cracks are rare but radial cracks are common, and the jointing is in places well developed producing pillow breccia.

The komatiitic basalt ejecta are mainly pyroclastic breccia mixed with agglomerate, together with some tuffaceous portions. The pyroclasts of the amphibole rock are poorly, rounded or fluidal-shaped with or without chilled skins, whereas the pyroclasts of the amphibole-plagioclase rock are usually subangular. The vesicularity of the scoriaceous bombs and lapilli is concentrated at the centre, but the amygdules in the accessory ejecta occasionally have a planar arrangement (Fig. 11).

The epiclastic volcanic conglomerate is crudely stratified and miscellaneously packed. The pebbles and cobbles in this monomictic conglomerate blanket are amphibole rock and pri-

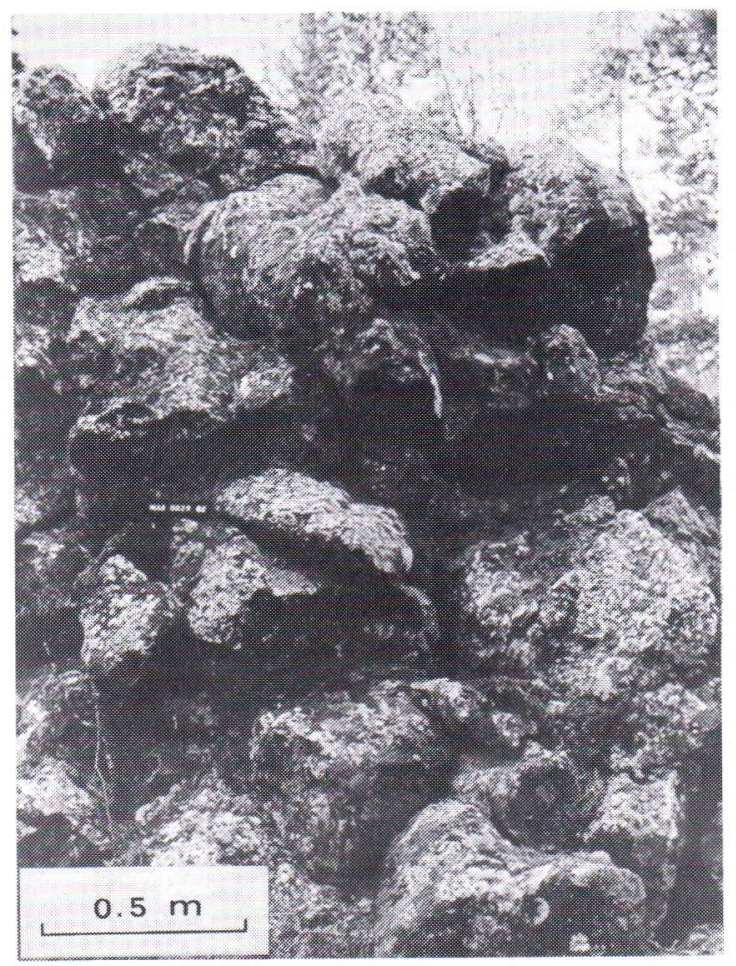

Fig. 9. An accumulation of lava driblets in the komatiitic basalt. About $5 \mathrm{~km}$ northwest of Sattasvaara. Photo by the author. 


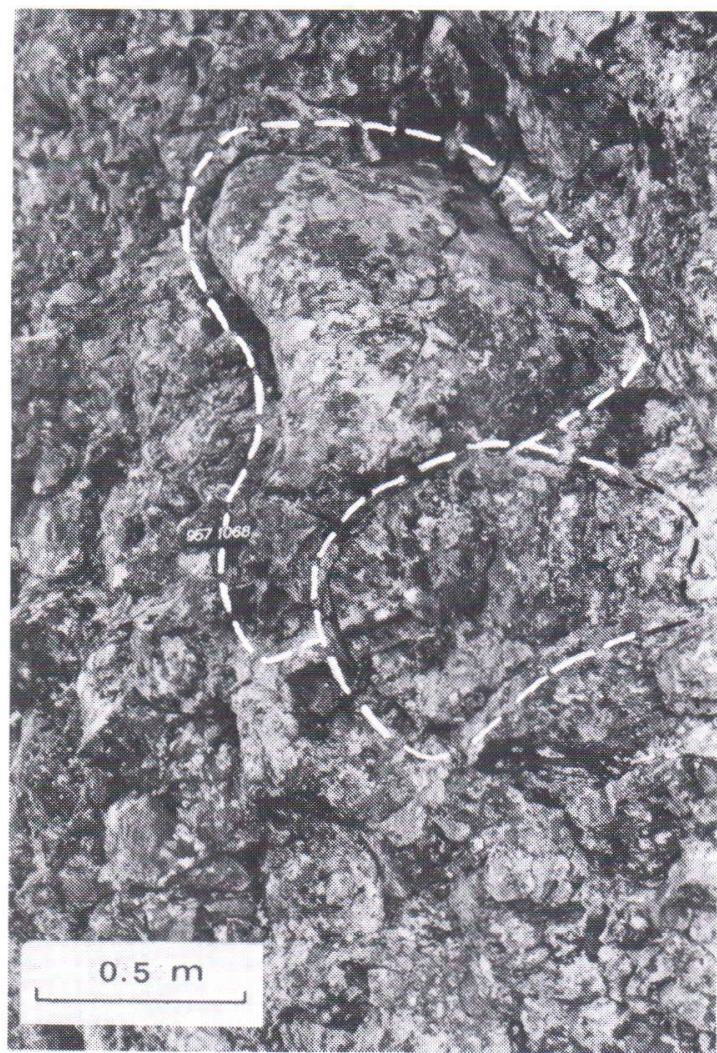

Fig. 10. Pillowed komatiitic basalt in which two pillows are delineated with dashed lines. Upper northern part of the stratigraphic section line in Figure 7. Photo by Saverikko (1978).

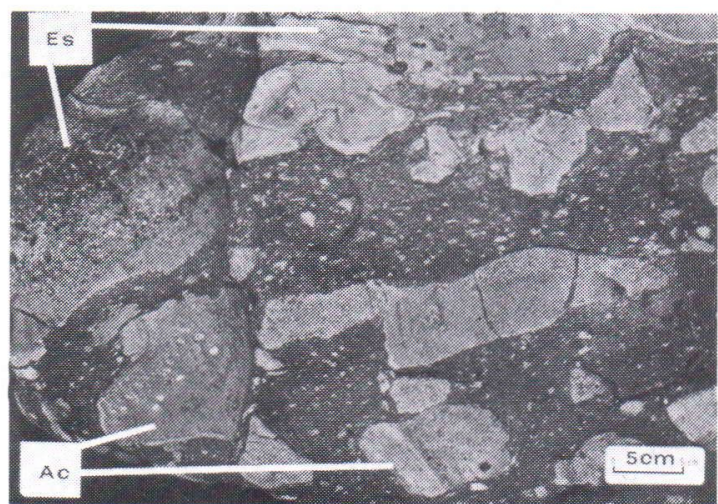

Fig. 11. Komatiitic basalt agglomerate with essential (Es) and accessory (Ac) bombs. Loose boulder found about 2 $\mathrm{km}$ west of the Kitinen river, beside Route E4. Photo by the author. marily subrounded and rounded. The matrix consists mostly of chlorite, mica and amphibole.

The lowermost deposit of komatiitic basalt in the eastern part of the complex, directly on the graphitic slate zone, is thinly stratified volcanic siltstone. The presence of several well-rounded lava cobbles indicates that the clastic material is partly epiclastic in origin. At the same time clinkery lapilli show the appearance of the original or slightly reworked pyroclastic material indicating that the deposit is part of the pyroclastic formation. The siltstone contains pebbly interlayers, and the uppermost stratum consists of sequence of 3-m-thick beds separated by depositional unconformities (Fig. 12). Stratigraphic analogies suggest that the volcanic siltstone is associated with the epiclastic volcanic conglomerate, and that the two lower lava piles and the (basaltic)komatiite interlayer (Fig. 5) are lacking in the eastern part of the complex.

The massive lavas are essentially monomineralic consisting of green or pale green amphibole laths with weak to strong pleochroism. Colourless tremolite laths are sparse if they occur at all and larger bluish green hornblende stalks contain bleached patches considered to be greenish actinolite. Fine-grained plagioclase is evenly distributed and present also in aggregates along with epidote. Within this nematoblastic groundmass are scattered polyhedral phenocrysts $(\varnothing$ $0.1-1 \mathrm{~mm}$ ) replaced by hornblende-actinolite. Accessory minerals are epidote, chlorite, carbonate, sphene and opaque mineral.

The most autobrecciated margins in the massive lava flows are composed of autoclasts with corroded core and smooth crust. The cores consist of cryptocrystalline amphibole and of minor chlorite present as dissemination and sparse devitrified glassy droplets. Saussuritic mineral dust defines flow textures and is concentrated into margins of the cores. The cores enclose polyhedral pseudomorphs $(\varnothing 0.1-0.3$ $\mathrm{mm}$ ) as monocrystalline greenish actinolite, and finely granular feldspathic ocelli $(\varnothing 0.1-2 \mathrm{~mm})$ 


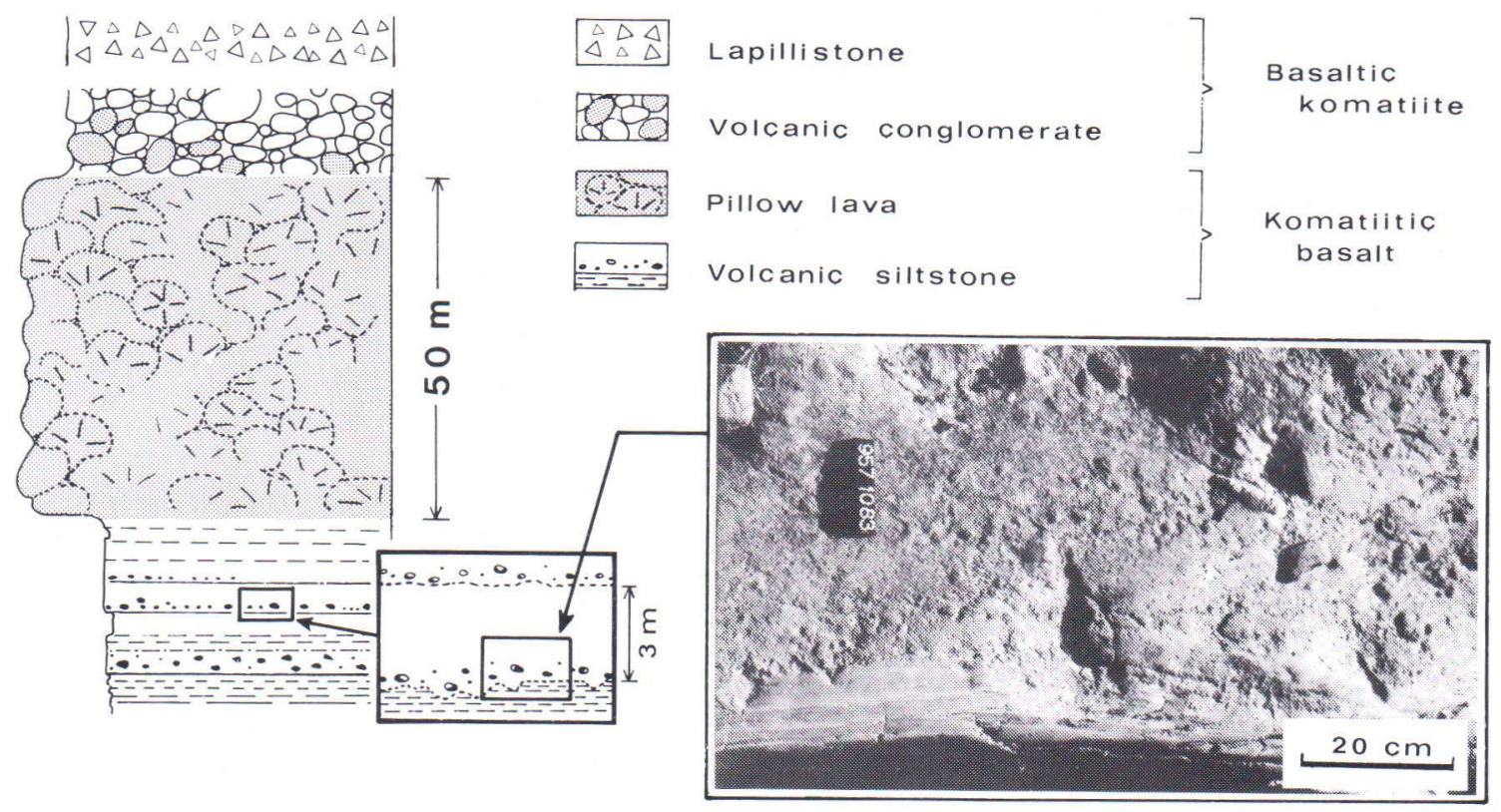

Fig. 12. Stratigraphic record of the komatiite complex in the eastern bank of the Kitinen river. Photo by Saverikko (1978).

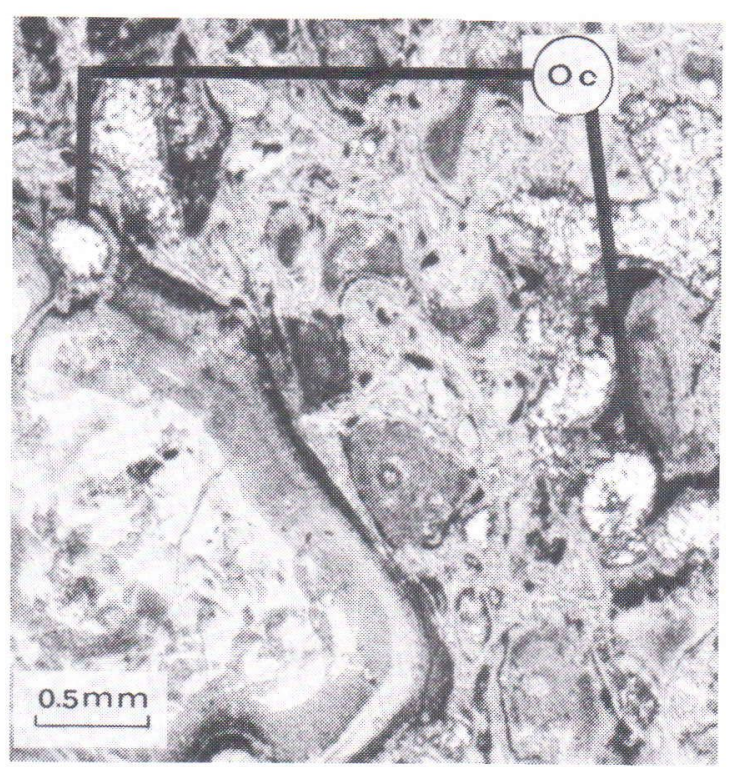

Fig. 13. Microphotograph from autobrecciated komatiitic basalt lava. Darker coloured matter is saussuritized and clear droplets are ocelli (Oc). Plane-polarized light transmitted. About $6 \mathrm{~km}$ east of Sattasvaara. Photo by J. Vää-

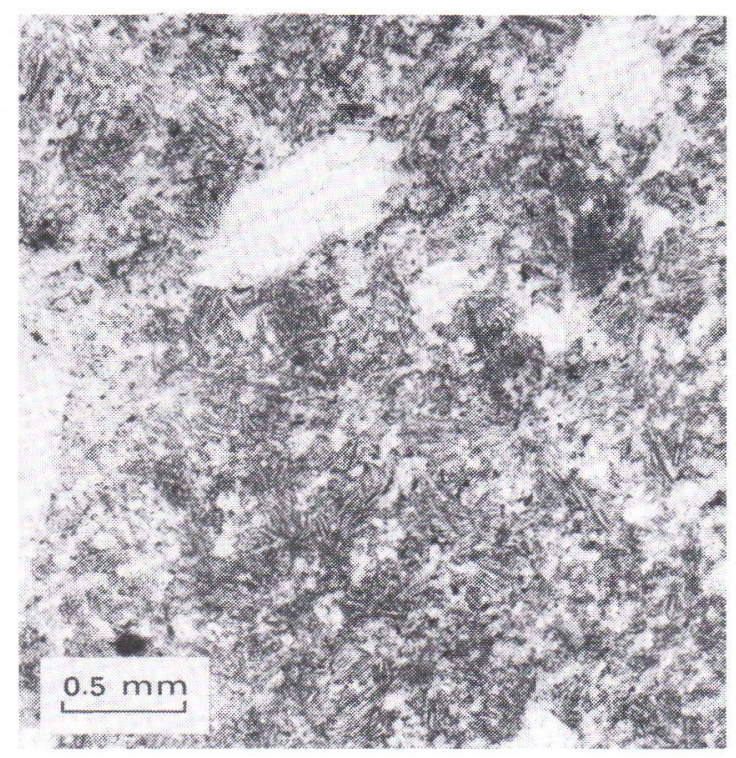

Fig. 14. Chloritized phenocrysts in the microlitic groundmass of the komatiitic basalt pillow-lava. Plane-polarized light transmitted. About $10 \mathrm{~km}$ east of Sattasvaara. Photo by $\mathrm{J}$. Väätäinen. 
in which the larger grains are plagioclase and the borders spherulitic amphibole (Fig. 13). The cored autoclasts with poorly saussuritized crust are mostly joined and monomineralic interstices are pale green actinolite and occasionally finegrained plagioclase or chlorite patches with epidote.

The lava pillows are microporphyritic; polyhedral phenocrysts $(\varnothing 0.1-2 \mathrm{~mm})$ are strongly chloritized, including exceptionally plagioclase as relic of primary mineral species. Greenish actinolitic microlites are preserved in saussuritized cryptocrystalline mineral assemblage of the turbid groundmass (Fig. 14). Saussuritic planar elements may be relict microcracks. More strongly recrystallized groundmass is composed of actinolite, epidote in sugar-like aggregates and minor chlorite. One magnesium-enriched variant contains colourless tremolite along with actinolite.

The pyroclastics were originally lithic ejecta varying from fine ash to bombs and crystal fragments 0.1 to $1 \mathrm{~mm}$ in diameter. Vitric ejecta were not encountered, suggesting that volcanic glass is very rare if it occurs at all.

Lithic lapilli and coarse-ash particles consist of cryptocrystalline or fine-grained greenish actinolite, minor chlorite and feldspathic ocelli ( $\varnothing$ $0.05-0.1 \mathrm{~mm}$ ). Saussuritic mineral assemblage defines flow textures and is enriched into margins of essential ejecta; in accessory ejecta saussurite and opaque minerals fill breccial fractures. Lapilli and coarse-ash particles are knobby or corroded and fine-ash particles are well rounded. Some ocelli even appear to be distinct ash particles, and scattered crystal ejecta are replaced by greenish actinolite present as short prisms (Fig. 15), sometimes provided with augitic twinning. The matrix or fine ash is usually recrystallized to actinolite, plagioclase, chlorite and minor carbonate, epidote and opaque minerals.

\section{(Basaltic)komatiite}

The (basaltic)komatiite is amphibole-chlorite rock with a weathering surface varying from reddish or yellowish brown to greenish grey. The shade of brown becomes darker towards the Sattasvaara hill but the fresh surface is everywhere greenish grey. In addition to amphibole and chlorite the rocks contain serpentine, pyroxene, magnetite, sulphides and carbonate.

The lower (basaltic)komatiite layer is poorly exposed, but the well-exposed upper layer is predominantly pyroclastic with lavas noteworthy only to the west of Sattasvaara and in the easternmost part of the complex. Elsewhere, minor lava flows protrude sporadically out from the pyroclastic cover. In places these minor flows appear to represent initial phases of eruptions.

Lavas are fine-grained or aphanitic, massive or anisotropic, and flow-top breccias and block lavas (Fig. 16) are characteristically present. The flow-top breccias are $0.2-1.5 \mathrm{~m}$ thick and visible as a lumpy erosion surface showing subrounded and subangular smooth-faced fragments $(\varnothing 1-40 \mathrm{~cm})$. The fragments are closely

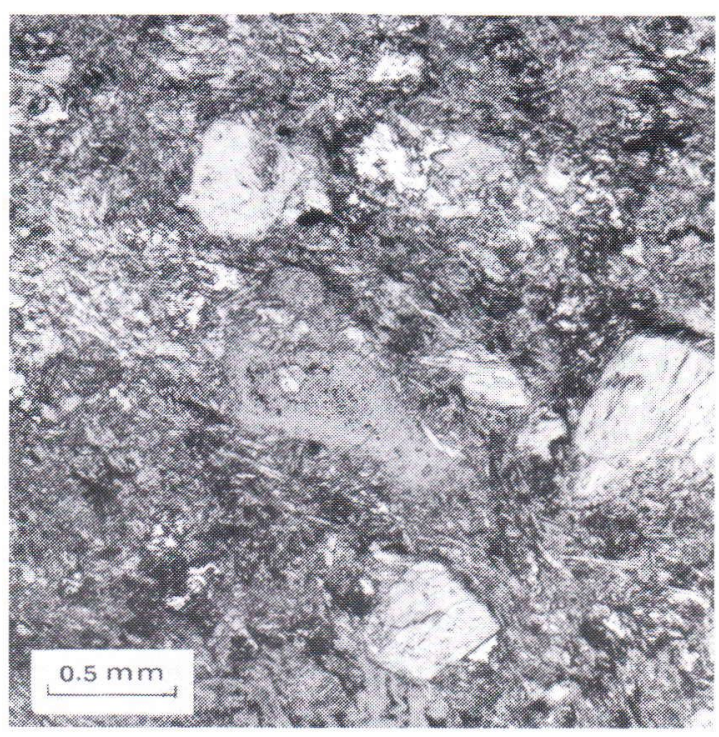

Fig. 15. Uralitized pyroxene present as lighter coloured crystal ejecta, and darker lithic lapilli in the stronger recrystallized matrix. Plane-polarized light transmitted. Eastern bank of the Kitinen river. Photo by J. Väätäinen. 

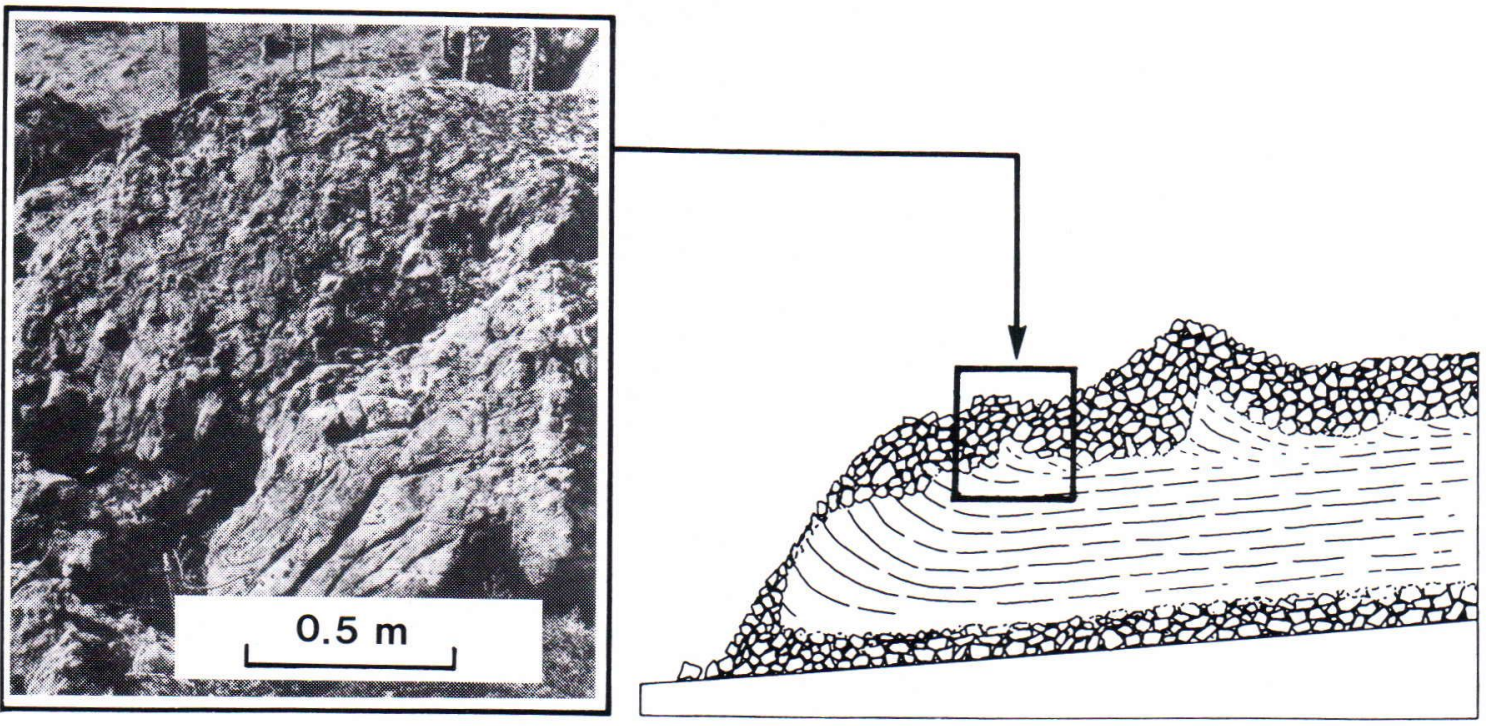

Fig. 16. Terminus of a block-lava flow, about $1 \mathrm{~km}$ southeast of Sattasvaara, and its approximate position in the schematic cross-section of the block lava described by Macdonald (1972, p. 94). Photo by Saverikko (1978).

fit and some of their jointed edges are covered with asbestos. Both the autobrecciated and massive flows are sharply separated by wrinkly contacts from the pyroclastic cover.

The block lavas grade from more massive flows and are composed of smooth-faced fragments $(\varnothing 3-60 \mathrm{~cm})$ which impress tightly on one another (Fig. 17). The few interstices that

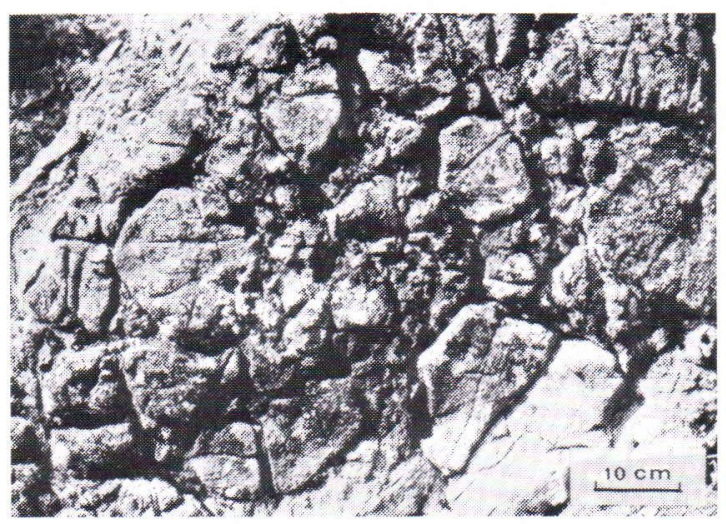

Fig. 17. Close-up view of the smooth and rounded fragments in the block lava shown in Figure 16. About $1 \mathrm{~km}$ southeast of Sattasvaara. Photo by the author.

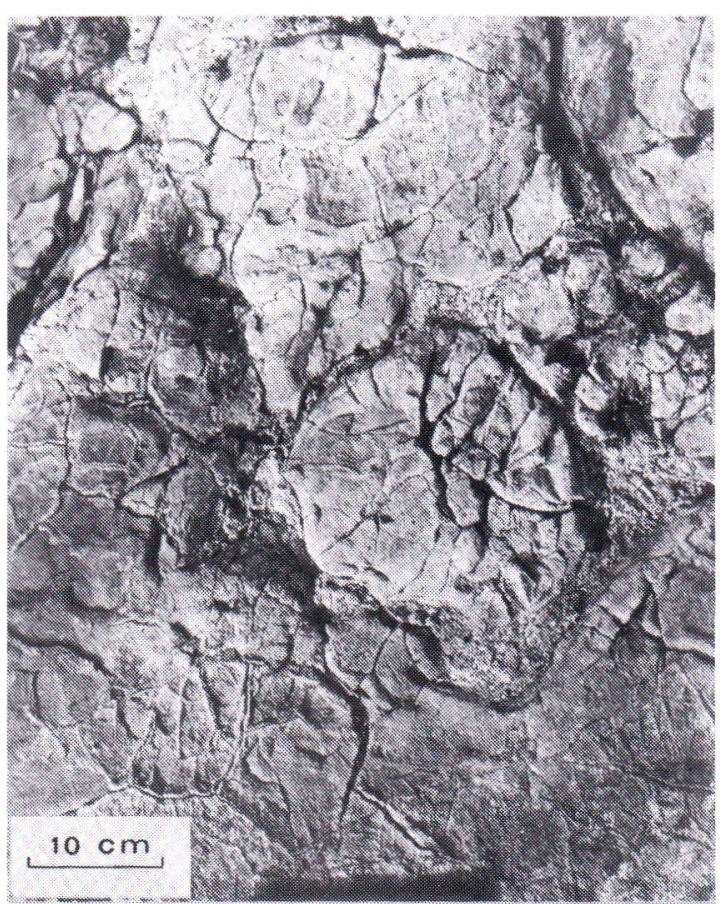

Fig. 18. Contact between massive and pillowed lavas in a (basaltic)komatiite flow. Beside Sattasvaara. Photo by the author. 
exist are filled with pyroclastic material. At the margins of the block-lava flows there are compactly accumulated fragments of lapillus size and the flows are sharply bounded by surrounding tuffaceous rocks.

A flow beside the cinder cone has formed a number of lava pillows in addition to the flowtop breccia (Fig. 18). Beneath the crust there are platy flow structures gently inclined away from the cone, and at a little deeper level the lava shows polygonal jointing. However, short cooling cracks with no systematic arrangement are more usual in the flows.

Lavas are weakly vesicular, containing carbonate amygdules $(\varnothing 0.1-2 \mathrm{~cm})$ of spherical, ellipsoidal or fusiform shape. Also present are irregularly shaped blisters $(\varnothing 0.1-1 \mathrm{~cm})$ filled with aphanitic chlorite, originally volcanic glass inclusions.

The pyroclastics are lapillistone, with lapilli tuffs and agglomerates sporadically accumulated into immature deposits with transitional boundaries. The coarsest ejecta are present as occasional bombs and blocks. The pyroclastic rocks are mainly massive and bedding appears only in the case of oriented or imbricated pyroclasts (Fig. 19). The amount of tuffaceous ejecta appears to increase with increasing distance from the cinder cone and accordingly the lapil-

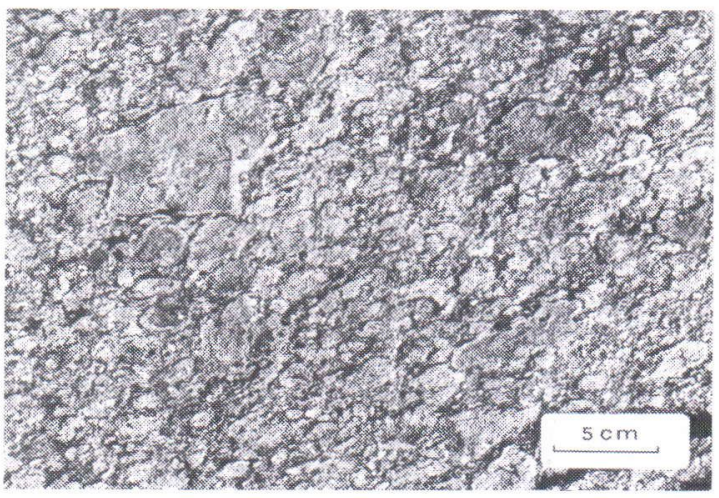

Fig. 19. Tightly packed lapillistone composed of cored lapilli or lapilli with chilled margin or of the both. Beside Sattasvaara. Photo by the author.

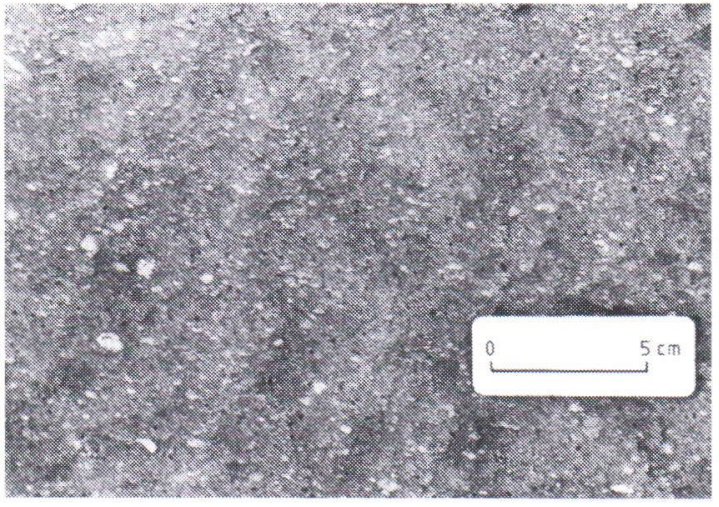

Fig. 20. Coarse tuff of (basaltic)komatiite containing many small lapilli visible as lighter clasts. West side of the Kitinen river. Photo by the author.

listones in the eastern part of the complex include tuff zones (Fig. 20). There is also a distinct lapilli-bearing tuff deposit beside the Sattasvaara cone, and on the southwestern side of the

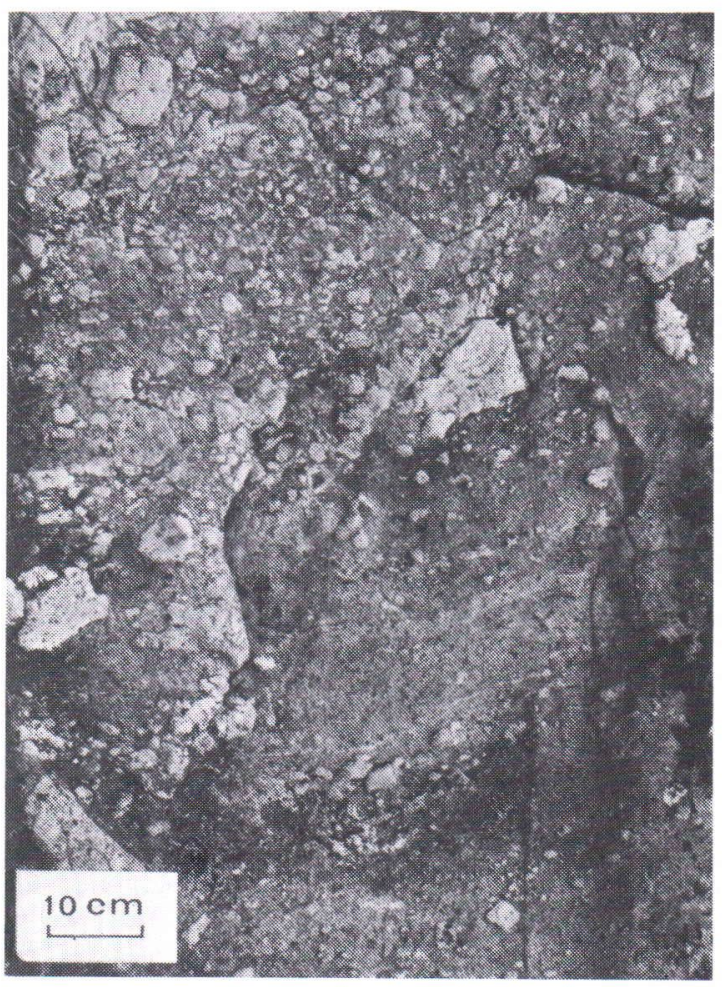

Fig. 21. Lapilli tuff of (basaltic)komatiite. About $9 \mathrm{~km}$ southeast of Sattasvaara. Photo by Saverikko (1978). 
Sattanen river the rock is tuff-rich, containing lapillistone interbeds and lapilli chains (Fig. 21).

The pyroclasts are in general poorly rounded, except for some rounded and fusiform lapilli. Ejecta of different shapes are mixed together and do not appear to form separate uniform deposits. The pyroclasts are smooth-faced or, occasionally, clinker-like and some of them are scoriaceous. Cored lapilli or lapilli with chilled margins or both occur everywhere in the deposit but mostly in and around the cinder cone. As resistant materials the pyroclasts are sharp-edged on the weathering surface but usually ghost-like on the fresh surface. Wholly distinct ejecta are slightly polymictic, evidently reworked or disintegrated.

The exotic clasts encountered are amphibole rock, amphibole-plagioclase rock, calc-silicate rock and magnetite. All are subrounded or rounded, except for one fusiform haematitemagnetite fragment of lapillus size.

The volcanic conglomerate at the bottom and southern border of the upper amphibole-chlorite rock contains rounded pebbles and cobbles of amphibole rock, amphibole-chlorite rock and amphibole-plagioclase rock, moderately packed and crudely stratified in chlorite-talc-amphibole matrix. Cored lapilli or lapilli with chilled margins are present as well and the conglomerate grades into lapillistone. On the eastern bank of the Kitinen river the conglomerate contains in addition several boulders of quartzfeldspathic rock; the well-rounded cobbles and boulders are tightly packed and stratification practically disappears.

The massive and slightly autobrecciated lavas are largely microporphyritic but containing also glassy inclusions, shards and autoclasts. Aphanitic lavas consist of cryptocrystalline colourless amphibole and minor chlorite and in places the groundmass contains tremolitic microlites and finely granular pyroxene among acicular colourless amphibole in reticular set. More strongly recrystallized tremolite or, exceptional- ly, actinolite with very weak pleochroism has formed needles and laths in random orientation and the abundant devitrified glassy droplets change from cryptocrystalline chlorite to chlorite patches.

Rounded or polyhedral phenocrysts $(\varnothing$ $0.2-3 \mathrm{~mm}$ ) are accumulated in the lower part of the lavas. Usually they are present as pseudomorphs but clinopyroxene - augite and diopside (Mikkola 1941, Papunen 1977, Isomaa 1978) is not always completely tremolitized. Strongly recrystallized phenocrysts appear as relicts defined by opaque mineral dust in aggregates of tremolite stalks. A few tremolitized pseudomorphs show relic crystal cleavage typical of olivine, but pseudomorphs with obvious olivine morphology are tiny dense aggregates of serpentine, chlorite and colourless amphibole.

In addition to devitrified glassy droplets the lavas contain vitric fragments in autoclastbearing layers and larger vitrophyric blisters in accumulative lower portions. Devitrified fragments occur as shards and fluidal-shaped inclu-

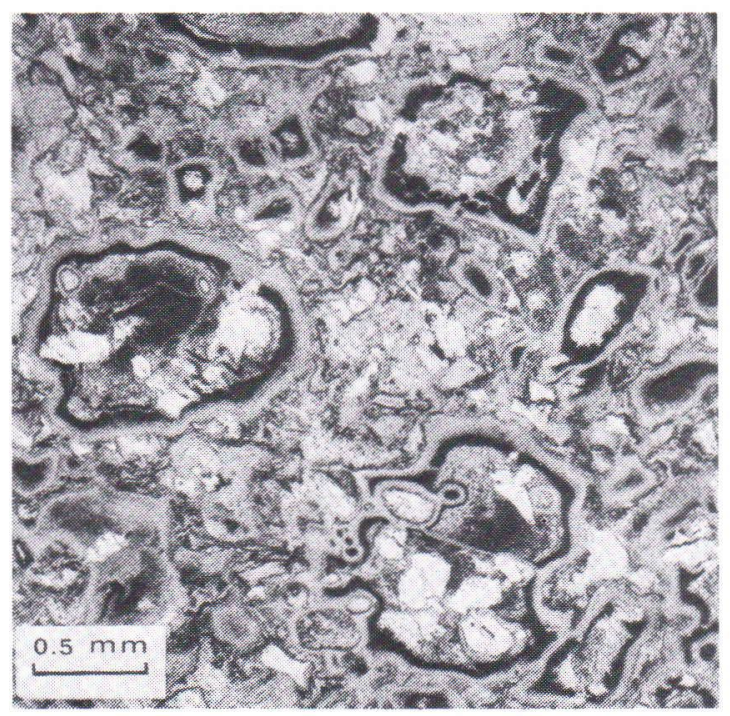

Fig. 22. Microphotograph from clinkers consisting the blocks in the block lava shown in Figures 16 and 17. Planepolarized light transmitted. About $1 \mathrm{~km}$ southeast of Sattasvaara. Photo by J. Väätäinen. 
sions. Because komatiitic glass tends to serpentinize (Williams 1971), the chlorite-serpentine shards are sometimes indistinguishable from crystal-faced pseudomorphs that originated from olivine. The blisters are devitrified to chlorite, serpentine and minor opaque mineral.

Fragments in the block lavas are autobrecciated consisting of bipartite autoclasts (Fig. 22) in which the material of the clear or turbid core is similar to the lava groundmass and often displays flow-textures. The cores, usually corroded and distorted, are surrounded with a saussuritic mineral-dust rim and these clinkers are wrapped in slightly turbid lava of the same mineral composition as the cores. The outer faces are smooth or weakly wrinkled and commonly joined. Some clinkers are porphyriticmicrolithic and a few have prismatic pseudomorphs as their core.

The pyroclastic rocks were originally built up of lithic, vitric and crystal ejecta in variable proportions. The lithic pyroclasts are almost entirely lapilli and coarse ash particles, the vitric pyroclasts are predominantly droplets and shards

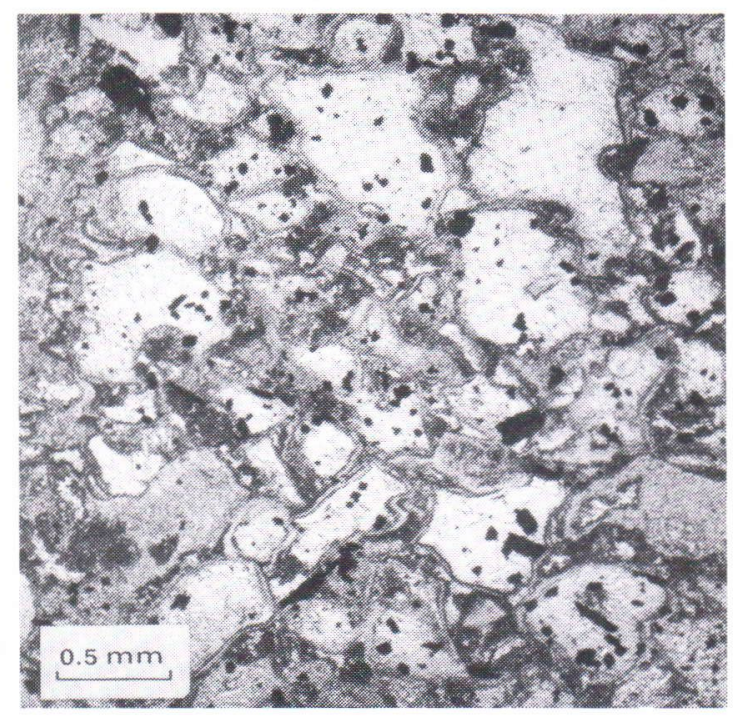

Fig. 23. Clear vitric and grey lithic ash particles in the (basaltic)komatiite tuff. About $1 \mathrm{~km}$ east of Sattasvaara. Plane-polarized light transmitted. Photo by J. Väätäinen. in ash-size range with some small lapilli, and the crystal ejecta appear to be $0.02-1.2 \mathrm{~mm}$ in diameter.

The lithic pyroclasts are flow-textured with streched glassy inclusions and similar to the aphanitic lavas. The contacts of the smoothfaced and corroded clasts with the chlorite-rich matrix are distinct or diffuse.

The vitric ejecta are widely distributed and mixed with the lithic ejecta, and also form a distinctive vitric tuff near the Sattasvaara hill. Ash particles are spherical, subangular or angular, concave-faced, irregularly shaped and corroded (Fig. 23). The scattered vitric lapilli are cryptocrystalline chlorite and serpentine enclosing small solid or skeletal prisms of clinopyroxene (Fig. 24). Where best preserved the lapilli are amorphous material with vitreous luster and impurities in the devitrified glass are visible as sets of acicular tremolite, enclosing pure droplets and polyhedral pseudomorphs. In addition to serpentinization the komatiitic glass appears to be susceptible to carbonatization.

The crystal ejecta are widespread minor con-

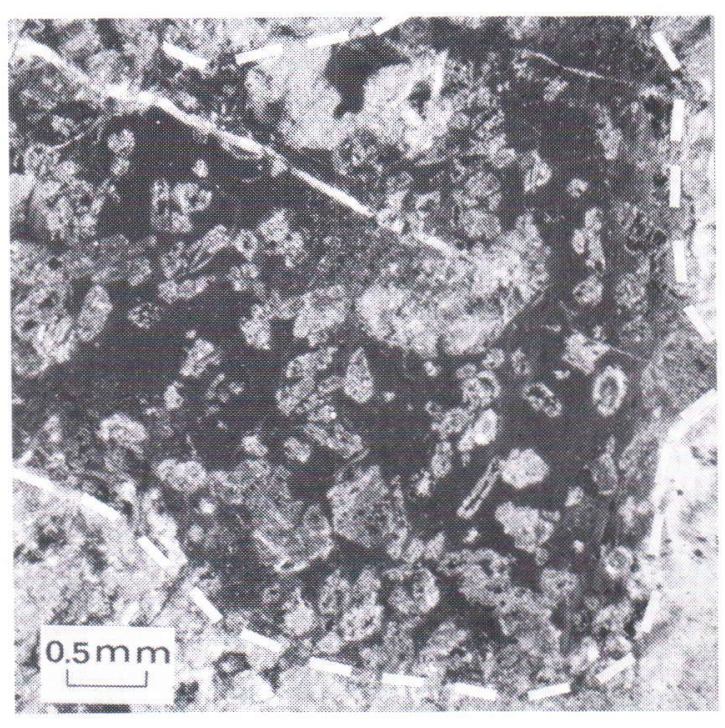

Fig. 24. Glassy lapillus enclosing tremolitized crystals. Boundary of the pyroclast marked with dashed line. Crossed polars. About $1 \mathrm{~km}$ north of Sattasvaara. Photo by J. Väätäinen. 
stituents, except in a tuffaceous deposit beside the cinder cone, which has crystal-tuff matrix hosting coarser lithic and vitric ejecta (Fig. 25). Crystals, both whole and broken, are clinopyroxene and olivine in various stages of preservation. They are euhedral or subhedral and some of the pyroxene crystals are granulated. Olivine is replaced by serpentine and chlorite, and pyroxene, especially in scattered grains, is tremolitized appearing as monocrystalline or polycrystalline pseudomorphs, aggregates of tremolite laths and bladed tremolite stalks.

Lithic-vitric matrix is not always distinguishable from the ejecta described above. In particular the ejecta in the cinder cone look to have been squeezed together and, for example, vitric ash particles surrounded by glassy matrix are distinguishable only in their spherulitic amphibole rinds or optically continuous tremolite band (Fig. 26), inferred to be welded contacts.

Reworked pyroclasts or epiclasts, lithic as well as vitric, are well-rounded and sometimes more strongly recrystallized or replaced than the surrounding material. The exterior face cutting

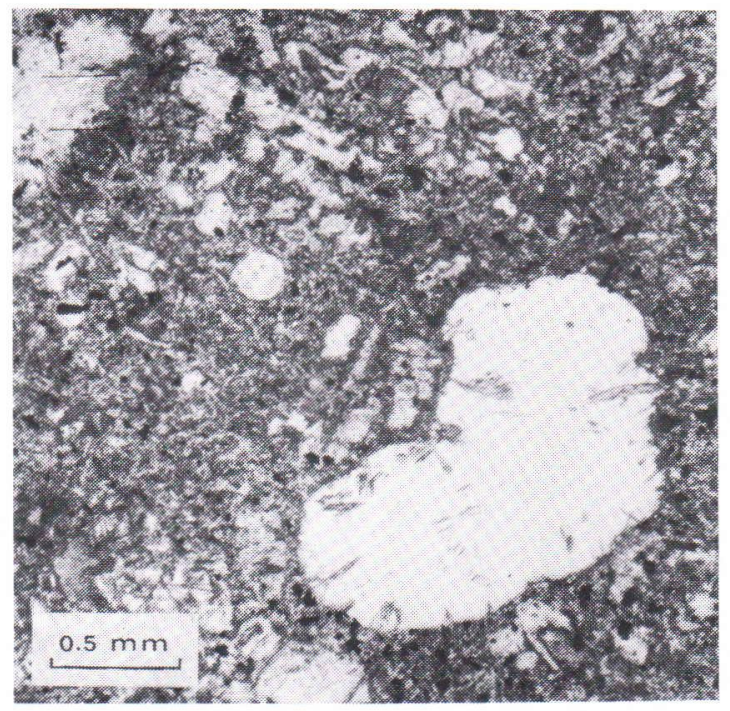

Fig. 25. Crystal tuff and floating vitric lapilli. Planepolarized light transmitted. About $1 \mathrm{~km}$ north of Sattasvaara. Photo by J. Väätäinen. interior textures and the roundness of the clasts together are a strong indication that this is secondary volcanic debris; smooth grain boundaries and polymictic appearance alone are not always diagnostic.

\section{Greenstone and greenschists}

Greenstone and greenschists build up a bipartite rock unit overlying the Sattasvaara complex. Upon the lower greenschists, the (basaltic) komatiite layer terminates in few lava flows and lapilli tuffs, that are present as intertonqued bodies beneath the upper greenstone. The interface between the greenschists and greenstone is covered also with sporadic conglomerate lobes or lenses.

The greenschists make up a heterogeneous rock pile manifested as a distinct electric conductor owing to disseminated graphite and sulphides. In its more resistant parts, the schist pile consists, in stratigraphic order, of phyllite with sericitic quartzite interlayers, graphitic slate, greywacke and, at the top, graphitic carbonate-

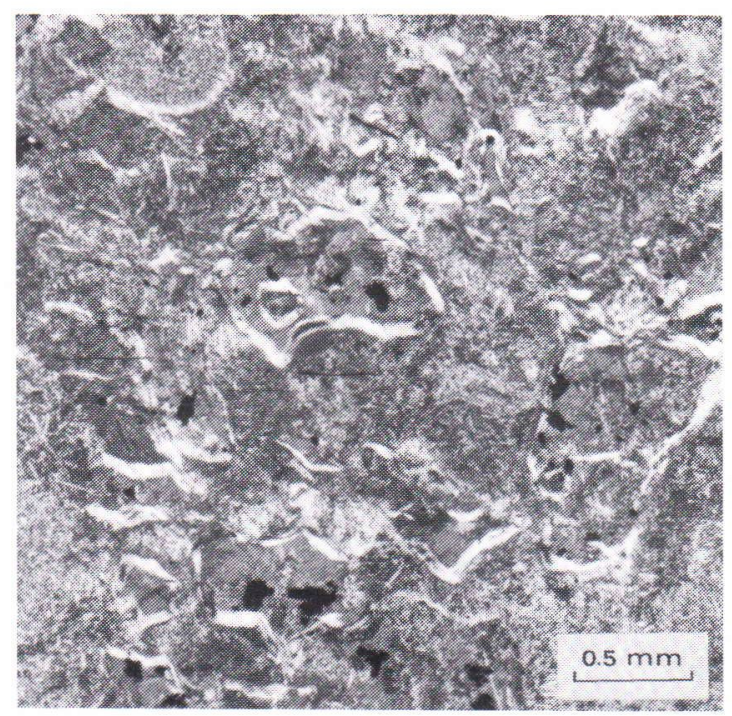

Fig. 26. Vitric ash particles provided with tremolitic margin inferred to present welded contacts. Crossed polars. Sattasvaara. Photo by J. Väätäinen. 
chlorite slate; on its east edge the deposit is formed of volcanic conglomerate with greywacke interlayers, grading into tuffaceous amphibole-chlorite rock (Räsänen 1977). A magnetite-banded nodular chert (Räsänen 1977) in association with the carbonaceous greenschists may belong to the suite of jaspilitic iron ores at Porkonen and Pahtavaara, about $10 \mathrm{~km}$ west of the study area. The iron ores also are closely associated with carbonaceous greenschists which in turn are similar to phyllites, with no sign of aluminium-rich detritus, and to greywackes epiclastic or pyroclastic in origin or both (Paakkola 1971).

The minor conglomerates overlying the carbonaceous greenschists are present in loosely packed deposits with transitional lateral boundaries. The pebbles are metavolcanics, chert, quartz-feldspathic rock and greywacke and there are some greenstone fragments that look like lapilli.

The greenstone is amphibole-albite rock bearing epidote and chlorite, sometimes as major minerals. The amphibole is hornblende-actinolite, and plagioclase forms microlithes, phenocrysts and varioles. The massive rock is mostly structureless lava with minor scoriaceous margins. Slightly autobrecciated flows are occasionally present and some rounded fragments are pillowlike.

The greenstone forms also isolated volcanic conduits penetrating the Sattasvaara complex (Fig. 6), and the ophite sheets or dikes are mineralogically and chemically similar to the greenstone.

\section{Komatiite}

The three komatiite sheets within the graphitic slate zone are thickened eastwards, the thicknesses in the moderately dipping southern limb being, at the greatest, $250 \mathrm{~m}$ (Papunen et al. 1977) and in the nearly horizontal northern limb much less. Peridotitic rocks predominate, with the serpentinitic rocks encountered in the footwall or hanging wall or in both. Rock boundaries are both distinct and diffuse, and in one outcrop the serpentinitic rock encloses peridotitic blocks. The vesicles, minor autobrecciated zones and other volcanic structures (Fig. 27) contained in the rocks indicate that the magmatic bodies are lava-flow piles, most probably extensive.

The dark grey peridotitic lava with brown weathering surface is mostly massive and coarsegrained or oriented and fine-grained, with py-

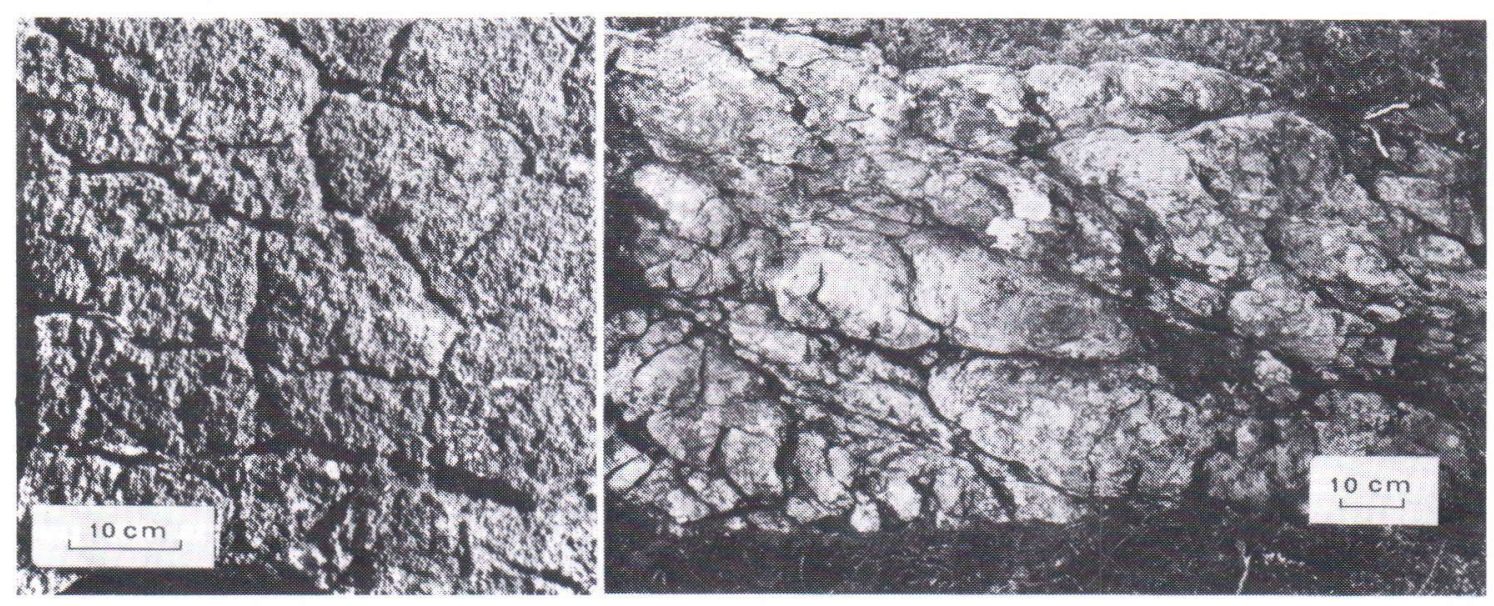

Fig. 27. Volcanic structures in the komatiite. Left: peridotitic rock showing polygonal jointing. Right: Serpentinitic rock composed of lava driblets. West side of the Kitinen river. Photos by the author. 
roxene and olivine as main minerals. The olivine in cumulus crystals surrounded by augite and hyperstene is serpentinized in varying degree, and the pyroxenes are partially uralitized and chloritized. The greyish green serpentinitic lava is composed predominantly of serpentine in pseudomorphs of olivine, and tremolite-actinolite, talc and chlorite are present, sometimes as main minerals. Minor volcanic glass has decomposed to cryptocrystalline chlorite and serpentine. Disseminated chromite, magnetite and sulphides occur as accessory minerals in the both lava types (Papunen et al. 1977, Isomaa 1978). The lavas seem in fact to be completely accumulative rocks and the serpentinitic rock may have been olivine-rich lava originally, because serpentinization occurs most strongly in komatiitic rocks with high olivine content (Williams 1971). Also, in microscopic examination the peridotitic lava is found to contain less primary olivine than the serpentinitic lava.

As a contact-metamorphic feature the rocks contain idioblasts $(\varnothing 0.5 \mathrm{~cm})$ of pyroxene in the border toward the Koitelainen gabbro complex. Their amount and size decrease drastically in the subhorizontal lava sheets with increasing distance from the gabbro.

The minor komatiite flows and picrite plugs within the upper (basaltic)komatiite layer of the Sattasvaara complex are petrographically and chemically similar to the above-mentioned komatiites. Increased amount of serpentine in the surrounding amphibole-chlorite rocks in places show that the serpentinites are at least partly cumulates of these rocks, but one peridotitic rock has formed a volcanic neck and a komatiite flow of which crust is autobrecciated amphibole-chlorite rock. Small distinct serpen-

Table 1. XRF analyses of amphibole rocks, originally lava flows in the Sattasvaara komatiite complex. Analysed by Väinö Hoffrén of the Geological Survey of Finland, Espoo.

\begin{tabular}{|c|c|c|c|c|c|c|c|c|c|c|c|}
\hline wt. $\%$ & 1. & 2. & 3. & 4. & 5. & 6. & 7. & 8. & 9. & 10. & 11. \\
\hline $\mathrm{SiO}_{2}$ & 45.33 & 46.80 & 46.59 & 47.22 & 46.16 & 48.80 & 47.69 & 47.19 & 46.24 & 46.30 & 52.72 \\
\hline $\mathrm{Al}_{2} \mathrm{O}_{3}$ & 7.95 & 9.26 & 11.66 & 9.79 & 10.18 & 8.55 & 9.79 & 11.11 & 11.59 & 5.81 & 11.62 \\
\hline $\mathrm{Fe}_{2} \mathrm{O}_{3}{ }^{+}$ & 12.20 & 12.31 & 12.92 & 14.04 & 13.66 & 12.36 & 13.83 & 12.49 & 14.89 & 9.33 & 11.89 \\
\hline $\mathrm{MgO}$ & 17.73 & 14.45 & 10.11 & 13.96 & 13.68 & 13.64 & 12.80 & 12.12 & 10.57 & 22.13 & 7.81 \\
\hline $\mathrm{CaO}$ & 8.68 & 9.68 & 11.20 & 10.57 & 9.52 & 8.81 & 9.16 & 10.09 & 9.57 & 7.71 & 6.80 \\
\hline $\mathrm{Na}_{2} \mathrm{O}$ & 1.33 & 1.99 & 1.42 & 2.62 & 2.14 & 1.33 & 3.14 & 2.00 & 2.43 & .00 & 5.71 \\
\hline $\mathrm{K}_{2} \mathrm{O}^{++}$ & .04 & .07 & .00 & .07 & .09 & .05 & .13 & .04 & .11 & .00 & .00 \\
\hline $\mathrm{MnO}$ & .19 & .21 & .19 & .25 & .26 & .18 & .21 & .19 & .24 & .13 & .15 \\
\hline $\mathrm{TiO}_{2}$ & .62 & .66 & 1.08 & .74 & .79 & .65 & .73 & .88 & 1.21 & .37 & .77 \\
\hline $\mathrm{P}_{2} \mathrm{O}_{5}$ & .00 & .03 & .06 & .00 & .04 & .05 & .07 & .08 & .10 & .03 & .08 \\
\hline Total & 94.07 & 95.46 & 95.23 & 99.26 & 96.52 & 94.42 & 97.55 & 96.19 & 96.95 & 91.81 & 97.55 \\
\hline $\mathrm{CaO} / \mathrm{Al}_{2} \mathrm{O}_{3}$ & 1.09 & 1.05 & 0.96 & 1.08 & 0.94 & 1.03 & 0.94 & 0.91 & 0.83 & 1.33 & 0.59 \\
\hline $\mathrm{Al}_{2} \mathrm{O}_{3} / \mathrm{TiO}_{2}$ & 12.82 & 14.03 & 10.80 & 13.23 & 12.89 & 13.15 & 13.41 & 12.62 & 9.58 & 15.70 & 15.09 \\
\hline
\end{tabular}

+ total $\mathrm{Fe}$ as $\mathrm{Fe}_{2} \mathrm{O}_{3}$

++ detection limit for $\mathrm{K}_{2} \mathrm{O}$ is $0.1 \mathrm{wt} . \%$

Samples:

1. Pillow lava, Paloseljänrolli. x 7501.56, y 484.88 .

2. - " - , Vanttion Rolli. x 7500.96, y 481.35.

3. - — , Paloseljänrolli. x 7501.06, y 483.74 .

4. Lava driblet in cone-like pile, Visakuppurat. x 7506.83, y 470.66.

5. Autobrecciated lava, Vanttion Rolli. x 7502.22, y 479.58 .
6. Massive lava, Kitinen river. x 7503.74, y 491.16.

7. - 》- , Visakuppurat. x 7506.82, y 470.65 (Tyrväinen 1983).

8. - »- Enonkotavaara. x 7505.43, y 487.40 (Tyrväinen 1983).

9. - \- , Visakuppurat. x 7506.47, y 471.20.

10. Cumulate, Paloseljänrolli. x 7500.76, y 485.74 .

11. Amygdaloid, Sattasen Liikavaara. x 7501.48, y 478.00. 
Table 2. XRF analyses of pyroclastic amphibole rocks in the Sattasvaara komatiite complex. Analysed by Väinö Hoffrén of the Geological Survey of Finland, Espoo.

\begin{tabular}{|c|c|c|c|c|c|c|}
\hline wt. $\%$ & 12. & 13. & 14. & 15. & 16. & 17. \\
\hline $\mathrm{SiO}_{2}$ & 45.64 & 43.99 & 47.95 & 48.39 & 51.19 & 52.66 \\
\hline $\mathrm{Al}_{2} \mathrm{O}_{3}$ & 7.97 & 10.58 & 11.67 & 10.70 & 10.64 & 12.06 \\
\hline $\mathrm{Fe}_{2} \mathrm{O}_{3}+$ & 12.58 & 12.67 & 11.77 & 12.67 & 11.22 & 11.81 \\
\hline $\mathrm{MgO}$ & 16.77 & 14.24 & 12.17 & 10.87 & 10.40 & 7.66 \\
\hline $\mathrm{CaO}$ & 6.47 & 9.47 & 7.88 & 11.34 & 6.32 & 8.06 \\
\hline $\mathrm{Na}_{2} \mathrm{O}$ & 1.05 & 2.25 & 3.46 & 2.58 & 3.49 & 5.18 \\
\hline $\mathrm{K}_{2} \mathrm{O}^{++}$ & .17 & .10 & .00 & .15 & .00 & .03 \\
\hline $\mathrm{MnO}$ & .27 & .19 & .21 & .21 & .26 & .20 \\
\hline $\mathrm{TiO}_{2}$ & .81 & .80 & .73 & .83 & .81 & .78 \\
\hline $\mathrm{P}_{2} \mathrm{O}_{5}$ & .06 & .04 & .04 & .06 & .08 & .10 \\
\hline $\mathrm{CO}_{2}$ & .08 & - & - & - & - & - \\
\hline $\mathrm{H}_{2} \mathrm{O}$ & 5.88 & - & - & - & - & - \\
\hline Total & 97.75 & 94.33 & 95.88 & 97.80 & 94.41 & 98.54 \\
\hline $\mathrm{aO} / \mathrm{Al}_{2} \mathrm{O}_{3}$ & & & & & & 0.67 \\
\hline $\mathrm{Al}_{2} \mathrm{O}_{3} / \mathrm{TiO}_{2}$ & 9.84 & 13.22 & 15.99 & 12.89 & 13.14 & 15.46 \\
\hline \multicolumn{7}{|c|}{$\begin{array}{l}\text { - not determined } \\
+ \text { total } \mathrm{Fe} \text { as } \mathrm{Fe}_{2} \mathrm{O}_{3} \\
++ \text { detection limit for } \mathrm{K}_{2} \mathrm{O} \text { is } 0.1 \text { wt. } \%\end{array}$} \\
\hline $\begin{array}{l}\text { Samples } \\
\text { 12. Lapilli } t \\
\text { 13. }-»- \\
\text { 14. }-»-\end{array}$ & $\begin{array}{l}\text { f, An } \\
\text {, Kit } \\
\text {, Ko }\end{array}$ & $\begin{array}{l}\text { kans } \\
\text { en ri } \\
\text { Van }\end{array}$ & $\begin{array}{l}x 7 \\
\text { elk }\end{array}$ & $\begin{array}{l}.00 \\
750\end{array}$ & $0, y$ & 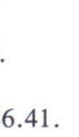 \\
\hline
\end{tabular}

tinites just outside the study area are intersected by greenstone dikes of similar chemical composition to the surrounding pillow lavas (Papunen et al. 1977). The picrite plugs may therefore be closely connected with volcanism and belong to the komatiitic suite.

\section{Geochemical features}

The komatiitic rocks in Lapland are considered to be closely connected with the greenstones (Paakkola 1971, Papunen et al. 1979). Mikkola (1941) thought them to have been differentiated from picritic magma and regarded the amphibole-chlorite rocks as a transitional rock suite between the ultrabasic and basic rocks; the serpentine/olivine-bearing varieties present only in

15. -»- , - - - x 7503.66, у 486.76 .

16. - - - Visasaari. x 7494.03, y 476.70 .

17. Pyroclastic breccia, Postovaara. x 7507.20, y 480.48 .

Table 3. XRF analyses of amphibole-chlorite rocks, originally lava flows in the Sattasvaara komatiite complex. Analysed by Väinö Hoffrén of the Geological Survey of Finland, Espoo.

\begin{tabular}{|c|c|c|c|c|c|c|c|c|c|c|}
\hline wt. $\%$ & 18. & 19. & 20. & 21. & 22. & 23. & 24. & 25. & 26. & 27. \\
\hline $\mathrm{SiO}_{2}$ & 43.30 & 42.94 & 46.25 & 43.56 & 43.46 & 38.32 & 42.08 & 38.32 & 40.06 & 43.58 \\
\hline $\mathrm{Al}_{2} \mathrm{O}_{3}$ & 4.41 & 5.94 & 5.11 & 6.02 & 9.45 & 11.06 & 8.37 & 6.55 & 5.98 & 6.10 \\
\hline $\mathrm{Fe}_{2} \mathrm{O}_{3}+$ & 10.71 & 12.16 & 9.19 & 12.33 & 13.42 & 16.47 & 14.44 & 19.72 & 18.51 & 13.36 \\
\hline $\mathrm{MgO}$ & 27.40 & 23.30 & 22.58 & 21.78 & 18.48 & 17.49 & 20.57 & 21.41 & 21.70 & 23.20 \\
\hline $\mathrm{CaO}$ & 6.64 & 7.70 & 8.41 & 6.81 & 7.93 & 7.13 & 6.71 & 5.64 & 6.45 & 6.80 \\
\hline $\mathrm{Na}_{2} \mathrm{O}$ & .01 & .88 & .71 & .00 & 1.04 & .14 & 1.91 & 1.35 & .75 & .87 \\
\hline $\mathrm{K}_{2} \mathrm{O}^{++}$ & .01 & .00 & .00 & .00 & .00 & .07 & .00 & .00 & .00 & .00 \\
\hline $\mathrm{MnO}$ & .19 & .21 & .19 & .13 & .27 & .32 & .16 & .10 & .11 & .12 \\
\hline $\mathrm{TiO}_{2}$ & .45 & .47 & .44 & .66 & .73 & .87 & .72 & .53 & .52 & .52 \\
\hline $\mathrm{P}_{2} \mathrm{O}_{5}$ & - & .00 & .00 & .00 & .00 & .11 & .06 & .03 & .00 & .00 \\
\hline Total & 93.12 & 93.60 & 92.88 & 91.29 & 94.78 & 91.99 & 95.02 & 93.66 & 94.09 & 94.56 \\
\hline $\mathrm{CaO} / \mathrm{Al}_{2} \mathrm{O}_{3}$ & 1.51 & 1.30 & 1.65 & 1.13 & 0.84 & 0.64 & 0.80 & 0.86 & 1.08 & 1.11 \\
\hline $\mathrm{Al}_{2} \mathrm{O}_{3} / \mathrm{TiO}_{2}$ & 9.80 & 12.64 & 11.61 & 9.12 & 12.95 & 12.71 & 11.62 & 12.36 & 11.50 & 11.73 \\
\hline
\end{tabular}

- not determined

+ total $\mathrm{Fe}$ as $\mathrm{Fe}_{2} \mathrm{O}_{3}$

++ detection limit for $\mathrm{K}_{2} \mathrm{O}$ is 0.1 wt. $\%$

Samples:

18. Porphyritic lava, Järvilaki. x 7501.97, y 469.44 (Papunen 1977).

19. - - , Mikkuurova. x 7503.54, y 478.26.

20. -»- , - - . x 7503.22, y 478.26.

21. - »- Paskamaa. x 7506.24, y 473.76 .

22. Block lava, Sattasrimpi. x 7501.74, y 475,14.

23. Massive lava, Sokkapetäjänvaara. x 7508.92, y 465.86. 24.-27. Flow unit from the bottom to the top, beside Sattasvaara. x 7502.74, y 473.18. 
and around the Sattasvaara hill, he classed with the ultrabasic metavolcanic rocks.

The komatiitic suite in the Sattasvaara area is grouping well into ultramafic volcanics, or komatiites, and komatiitic basalts according to the classification of Arndt and Nisbet (1982). The komatiitic basalt is amphibole rock but the ultramafic volcanics - the serpentinitic/peridotitic rocks and amphibole-chlorite rocks are mostly quite different in petrographic features and physical properties prevailed in the magmas (see p. 83): therefore they are called here komatiites and (basaltic)komatiites, respectively, after slightly indefinite manner recorded by Arndt and Brooks (1980). The adopted nomenclature is not the best, because the rocks known previously as basaltic komatiites belong under the komatiitic basalt defined by Arndt and Nisbet (1982), except for the basaltic komatiite of the Geluk type (Viljoen and Viljoen 1969, Viljoen et al. 1982), that is chemically similar to the amphibole-chlorite rock in the Sattasvaara complex. The distinctly paired ultramafic volcanic rock suite occurs also elsewhere in this pyroclastic komatiite zone (Henriksen 1983, Saverikko 1983), what may be unusual in Archean greenstone belts.

The komatiitic basalt (Tables 1-2) and (basaltic)komatiite (Tables 3-4) in the Sattasvaara complex constitute a transitional rock series

Table 4. XRF analyses of pyroclastic amphibole-chlorite rocks in the Sattasvaara komatiite complex. Analysed by Väinö Hoffrén of the Geological Survey of Finland, Espoo.

\begin{tabular}{|c|c|c|c|c|c|c|c|c|c|c|c|c|c|c|c|}
\hline wt. $\%$ & 28. & 29. & 30. & 31. & 32. & 33. & 34. & 35. & 36. & 37. & 38. & 39. & 40. & 41. & 42. \\
\hline $\mathrm{SiO}_{2}$ & 41.19 & 44.35 & 42.85 & 43.95 & 44.17 & 41.64 & 43.47 & 42.08 & 46.15 & 46.70 & 43.85 & 41.72 & 43.00 & 42.20 & 43.68 \\
\hline $\mathrm{Al}_{2} \mathrm{O}_{3}$ & 6.59 & 4.38 & 5.04 & 5.47 & 5.99 & 6.54 & 5.77 & 5.73 & 5.43 & 6.21 & 5.63 & 6.98 & 6.64 & 6.95 & 8.40 \\
\hline $\mathrm{Fe}_{2} \mathrm{O}_{3}{ }^{+}$ & 10.05 & 10.24 & 11.37 & 9.70 & 12.50 & 14.35 & 11.68 & 12.61 & 11.17 & 8.73 & 13.76 & 12.05 & 11.46 & 11.33 & 12.12 \\
\hline $\mathrm{MgO}$ & 26.55 & 26.16 & 25.87 & 25.62 & 24.06 & 24.05 & 24.03 & 22.94 & 22.45 & 22.18 & 21.09 & 24.69 & 24.13 & 21.17 & 19.26 \\
\hline $\mathrm{CaO}$ & 6.04 & 8.46 & 7.60 & 7.26 & 6.04 & 5.54 & 7.69 & 6.16 & 8.37 & 8.20 & 6.07 & 5.87 & 7.26 & 6.38 & 7.63 \\
\hline $\mathrm{Na}_{2} \mathrm{O}$ & .24 & .00 & .00 & .00 & .66 & .57 & .78 & .00 & .53 & .82 & .26 & .83 & .88 & .42 & 1.41 \\
\hline $\mathrm{K}_{2} \mathrm{O}^{++}$ & .15 & .02 & .01 & .03 & .00 & .00 & .00 & .00 & .00 & .00 & .03 & .00 & .00 & .00 & .00 \\
\hline $\mathrm{MnO}$ & .25 & .20 & .26 & .16 & .24 & .16 & .28 & .24 & .27 & .27 & .11 & .25 & .20 & .17 & .19 \\
\hline $\mathrm{TiO}_{2}$ & .88 & .53 & .51 & .38 & .57 & .61 & .59 & .65 & .65 & .58 & .57 & .55 & .55 & .46 & .50 \\
\hline $\mathrm{P}_{2} \mathrm{O}_{5}$ & .00 & - & - & - & .00 & .06 & .00 & .06 & .00 & .03 & .00 & .04 & .04 & .03 & .00 \\
\hline $\mathrm{CO}_{2}$ & 1.47 & - & - & - & - & - & - & .16 & - & - & - & - & - & - & - \\
\hline $\mathrm{H}_{2} \mathrm{O}$ & 6.33 & - & - & - & - & - & - & 6.82 & - & 一 & - & - & - & - & 一 \\
\hline Total & 99.74 & 94.34 & 93.51 & 92.57 & 94.23 & 93.52 & 94.29 & 97.45 & 95.02 & 93.72 & 91.37 & 92.98 & 94.16 & 89.11 & 93.19 \\
\hline & 0.92 & 1.93 & 1.51 & 1.03 & 1.01 & V & 1.33 & 1.07 & 1.54 & 1.52 & 1.08 & 0.84 & 1.09 & 0.92 & 0.91 \\
\hline $\mathrm{Al}_{2} \mathrm{O}_{3} / \mathrm{TiO}_{2}$ & 7.49 & 8.26 & 9.88 & 14.39 & 10.51 & 10.72 & 9.78 & 8.82 & 8.35 & 10.71 & 9.88 & 12.69 & 12.07 & 15.11 & 16.80 \\
\hline
\end{tabular}

- not determined

+ total $\mathrm{Fe}$ as $\mathrm{Fe}_{2} \mathrm{O}_{3}$

++ detection limit for $\mathrm{K}_{2} \mathrm{O}$ is $0.1 \mathrm{wt} . \%$

Samples:

28. Pyroclastic rock, Sattasvaara. (Mikkola 1941).

29. - - , — — . x 7504.15, y $474.15(\mathrm{~Pa}-$ punen 1977).

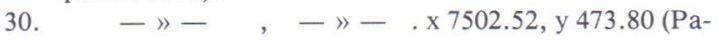
punen 1977).

31. - - , - - . x 7503.36, y $472.96(\mathrm{~Pa}-$ punen 1977).

32. Lapillistone, Sattasvaaranliikamaa. x 7504.26, y 473.48 .

33. Pyroclastic rock, Vanttion Kotavaara. x 7503.65, y 484.95 (Tyrväinen 1983).
34. Crystal tuff, Sattasvaaranliikamaa. x 7504.38, y 473.70.

35. Lapillistone, Sattasvaara. x 7502.82, y 473.79.

36. - »- , - - . х 7502.68, у 473.91.

37. -»- , -»- . х 7502.96, y 473.76 .

38. - - , Paskamaa. x 7506.20, у 473.95.

39. Lapilli tuff, Sattasrimpi. x 7501.66, y 475.70.

40. Tuff, Sattasrimpi. x 7502.00, y 475.22.

41. Lapilli tuff, Kitinen river. x 7503.86, y 491.10.

42. Matrix in volcanic conglomerate, Kitinen river. $x$ 7504.84, y 491.58. 
with chemical bimodality (Fig. 28), in which the limiting $\mathrm{MgO}$ content is 18 wt.\% (anhydrous basis). Transition appears microscopically as a change of the amphibole that is colourless tremolite in the (basaltic)komatiite and greenish or pale green actinolite in the komatiitic basalt. The replacement by tremolite or actinolite appears to be indicative of primary chemical differences between the lavas, since the earlier solidified clinkers in the autobrecciated komatiitic basalt flow, for example, are colourless or slightly greenish tremolite-actinolite, but the interstitial material solidified later is pale green actinolite. Hybrid rocks include both amphiboles.

The komatiitic basalt does not show any significant difference in the main element composition between the lavas and pyroclastics. $\mathrm{MgO}$ content is over $10 \mathrm{wt} . \%$ except for one amygdaloid and one mixed pyroclastic breccia. The pillow lavas appear to be rich in magnesium and poor in sodium as compared with the massive lavas. The cumulate of one massive flow is naturally most rich in magnesium and its chemical composition is similar to ordinary (basaltic) komatiites.

The samples of (basaltic)komatiite for anal-
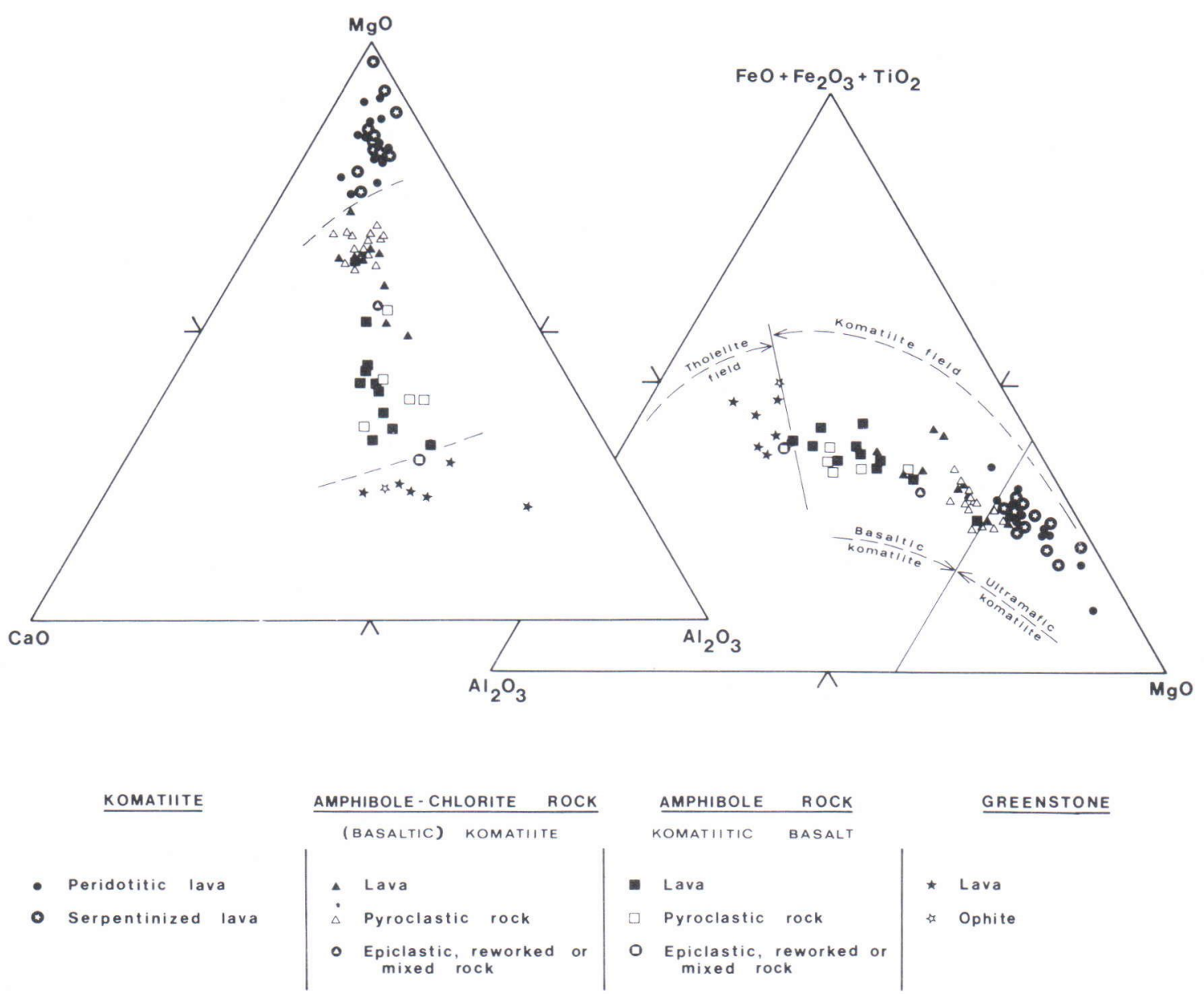

Fig. 28. Chemical composition of komatiitic rocks in the Sattasvaara area, presented on $\mathrm{CaO}-\mathrm{MgO}-\mathrm{Al}_{2} \mathrm{O}_{3}$ and $\mathrm{Al}_{2} \mathrm{O}_{3}-$ $\mathrm{FeO}+\mathrm{Fe}_{2} \mathrm{O}_{3}+\mathrm{TiO}_{2}-\mathrm{MgO}$ diagrams. The limit between ultramafic and basaltic komatiites is defined by Jensen (1976) and the limit separating the komatiite field is revised by Viljoen et al. (1982). 
yses have been selected predominantly from the upper amphibole-chlorite rock layer in which $\mathrm{MgO}$ content tends to increase upwards: the lowest $\mathrm{MgO}$ contents have been encountered in two initial lava flows, magnesium has enriched upwards in one flow unit in the lower part of the layer and the terminal ejecta in and around the cinder cone contain the highest $\mathrm{MgO}$ content, reaching finally compositional affinity with the komatiites. In addition to several cumulates in the (basaltic)komatiite lavas there are one or two terminal lava flows of peridotitic rock covered with only thin crust of amphibolechlorite rock, that link up a small peridotitic plug, or komatiite neck. However, most ejecta and lavas are uniform in composition having chemical similarities to the basaltic komatiite of the Geluk type, or to komatiitic magma characterized by frequent original pyroxene as well as some olivine (Viljoen and Viljoen 1969).

Slightly depleted $\mathrm{MgO}$ and enriched $\mathrm{Al}_{2} \mathrm{O}_{3}$ contents in the matrix of the volcanic conglomerate could be regarded as chemical evidence of detritus, although the anomalies are not so apparent as elsewhere in the detritus originated from the (basaltic)komatiite (Saverikko 1983). But aluminium enrichment in the fine-grained pyroclastic rocks may evidence fre-

Table 5. XRF analyses of peridotitic rocks. Analysed by Väinö Hoffrén of the Geological Survey of Finland, Espoo.

\begin{tabular}{|c|c|c|c|c|c|c|c|c|c|c|c|c|c|}
\hline wt. $\%$ & 43. & 44. & 45. & 46. & 47. & 48. & 49. & 50. & 51. & 52. & 53. & 54. & 55. \\
\hline $\mathrm{SiO}_{2}$ & 34.70 & 37.55 & 37.25 & 42.90 & 38.65 & 39.69 & 40.10 & 39.29 & 39.41 & 41.30 & 40.12 & 40.67 & 40.67 \\
\hline $\mathrm{Al}_{2} \mathrm{O}_{3}$ & 1.84 & 2.51 & 2.76 & 2.77 & 2.79 & 4.07 & 3.78 & 2.72 & 4.34 & 2.65 & 3.50 & 4.48 & 3.26 \\
\hline $\mathrm{Fe}_{2} \mathrm{O}_{3}{ }^{+}$ & 9.70 & 4.56 & 11.24 & 10.37 & 10.91 & 11.78 & 12.75 & 15.30 & 12.21 & 12.21 & 12.01 & 12.80 & 14.73 \\
\hline $\mathrm{MgO}$ & 41.06 & 39.16 & 34.40 & 32.80 & 31.86 & 30.34 & 30.20 & 30.10 & 29.55 & 28.68 & 27.41 & 26.07 & 23.72 \\
\hline $\mathrm{CaO}$ & 2.60 & 1.46 & 2.58 & 3.74 & 2.86 & 2.44 & 2.47 & 1.71 & 3.04 & 5.86 & 3.09 & 3.76 & 5.12 \\
\hline $\mathrm{Na}_{2} \mathrm{O}$ & .01 & .18 & .00 & .05 & .11 & .20 & .24 & .07 & .65 & .14 & .00 & .00 & .36 \\
\hline $\mathrm{K}_{2} \mathrm{O}^{++}$ & .00 & .01 & .00 & .01 & .01 & .00 & .00 & .00 & .00 & .03 & .00 & .00 & .00 \\
\hline $\mathrm{MnO}$ & .15 & .13 & .12 & .17 & .16 & .17 & .19 & .15 & .18 & .19 & .17 & .16 & .24 \\
\hline $\mathrm{TiO}_{2}$ & .17 & .24 & .23 & .51 & .27 & .29 & .21 & .36 & .33 & .31 & .43 & .25 & .34 \\
\hline $\mathrm{P}_{2} \mathrm{O}_{5}$ & - & - & - & - & - & .00 & .05 & .05 & .00 & - & .04 & .04 & .00 \\
\hline Total & 90.23 & 85.80 & 88.58 & 93.32 & 87.62 & 88.98 & 89.99 & 89.75 & 89.71 & 91.37 & 86.77 & 88.23 & 88.44 \\
\hline $\mathrm{CaO} / \mathrm{Al}_{2} \mathrm{O}_{3}$ & 1.41 & 0.58 & 0.93 & 1.35 & 1.03 & 0.60 & 0.65 & 0.63 & 0.70 & 2.21 & 0.88 & 0.84 & 1.57 \\
\hline $\mathrm{Al}_{2} \mathrm{O}_{3} / \mathrm{TiO}_{2}$ & 10.82 & 10.46 & 12.00 & 5.43 & 10.33 & 14.03 & 18.00 & 7.56 & 13.15 & 8.55 & 8.14 & 17.92 & 9.59 \\
\hline
\end{tabular}

- not determined

+ total $\mathrm{Fe}$ as $\mathrm{Fe}_{2} \mathrm{O}_{3}$

++ detection limit for $\mathrm{K}_{2} \mathrm{O}$ is 0.1 wt. $\%$

\section{Samples:}

43. Accumulative flow, Paskamaa. x 7508.69 , y 482.32 (Papunen 1977).

44. Picrite, Töyrylänmaa. X 7500.62, y 475.33 (Papunen 1977).

45. Accumulate flow, Moskuvaara. x 7506.98, y 489.82 (Papunen 1977).

46. $\quad-»-\quad$, Petkula. x 7510.40, y $491.60(\mathrm{~Pa}-$ punen 1977).

47. - \- , Souvaselkä. x 7504.32, y 498.50 (Papunen 1977).
48. Accumulative flow, Moskuvaara. x 7503.04, y 496.64 (Tyrväinen 1983).

49. - - - Vaiskonpalo. x 7515.05, y 497.05 (Tyrväinen 1983).

50. - - , Mataravaara. x 7506.26, y 489.46 .

51. - »- , Moskuvaara. x 7502.70, y 495.90 .

52. - »- , Souvaselkä. x 7506.54, y 500.98 (Papunen 1977).

53. - »- , Petkula. x 7510.36, y 491.58.

54. - - - Vaiskonpalo. x 7514,97, y 497.62.

55. - - , Moskuvaara. x 7501.84, y 496.24. 
Table 6. XRF analyses of serpentinitic rocks. Analysed by Väinö Hoffrén of the Geological Survey of Finland, Espoo.

\begin{tabular}{|c|c|c|c|c|c|c|c|c|c|c|c|}
\hline wt. $\%$ & 56. & 57. & 58. & 59. & 60. & 61. & 62. & 63. & 64. & 65. & 66. \\
\hline $\mathrm{SiO}_{2}$ & 40.20 & 40.70 & 40.34 & 42.70 & 42.20 & 39.82 & 39.13 & 41.90 & 40.79 & 41.70 & 38.57 \\
\hline $\mathrm{Al}_{2} \mathrm{O}_{3}$ & 2.24 & 2.82 & .76 & 3.07 & 3.29 & 3.27 & 3.75 & 4.27 & 3.80 & 3.15 & 4.32 \\
\hline $\mathrm{Fe}_{2} \mathrm{O}_{3}{ }^{+}$ & 12.18 & 13.53 & 9.73 & 8.04 & 9.47 & 13.03 & 10.76 & 10.25 & 12.25 & 13.20 & 12.44 \\
\hline $\mathrm{MgO}$ & 34.40 & 34.27 & 34.15 & 33.71 & 33.55 & 29.51 & 29.51 & 28.82 & 28.26 & 28.21 & 27.90 \\
\hline $\mathrm{CaO}$ & .97 & 3.37 & .39 & 3.49 & 3.49 & .75 & 2.92 & 5.75 & 2.81 & 4.81 & 2.34 \\
\hline $\mathrm{Na}_{2} \mathrm{O}$ & .00 & .00 & .00 & .01 & .07 & .00 & .28 & .04 & .06 & .15 & .25 \\
\hline $\mathrm{K}_{2} \mathrm{O}^{++}$ & .01 & .03 & .00 & .05 & .20 & .00 & .00 & .01 & .00 & .01 & .03 \\
\hline $\mathrm{MnO}$ & .05 & .18 & .17 & .11 & .17 & .03 & .18 & .16 & .07 & .18 & .16 \\
\hline $\mathrm{TiO}_{2}$ & .37 & .21 & .05 & .28 & .22 & .38 & .31 & .51 & .21 & .36 & .32 \\
\hline $\mathrm{P}_{2} \mathrm{O}_{5}$ & - & - & .00 & - & 一 & .04 & .00 & - & .04 & - & .03 \\
\hline Total & 90.42 & 95.11 & 85.59 & 91.46 & 92.66 & 86.83 & 86.84 & 91.71 & 88.29 & 91.77 & 86.36 \\
\hline $\mathrm{CaO} / \mathrm{Al}_{2} \mathrm{O}_{3}$ & 0.43 & 1.19 & 0.51 & 1.14 & 1.06 & 0.23 & 0.78 & 1.35 & 0.74 & 1.53 & 0.54 \\
\hline $\mathrm{Al}_{2} \mathrm{O}_{3} / \mathrm{TiO}_{2}$ & 6.05 & 13.43 & 15.20 & 10.96 & 14.95 & 8.61 & 12.10 & 8.37 & 18.10 & 8.75 & 13.50 \\
\hline
\end{tabular}

- not determined

+ total $\mathrm{Fe}$ as $\mathrm{Fe}_{2} \mathrm{O}_{3}$

++ detection limit for $\mathrm{K}_{2} \mathrm{O}$ is $0.1 \mathrm{wt} . \%$

Samples:

56. Accumulative flow, Mataravaara. x 7506.10, y 489.53 (Papunen 1977).

57. - - - Vaiskonpalo. x 7514.37, y 494.94 (Papunen 1977).

58. -»- Sokkapetäjänvaara. x 7508.92, y 465.86 .

59. - - — , Vaiskonpalo. x 7514.31, y 496.19 (Papunen 1977).

60. $\quad-»-\quad . \quad-»-\quad . \times 7514.62$, y 496.82 (Papunen 1977).

61. Accumulative flow, Mataravaara. x 7506.26, y 489.46 .

62. Picrite, Töyrylänmaa. x 7500.72, y 475.32 .

63. Accumululative flow, Vanttion Kotavaara. x 7503.14 y 485.02 (Papunen 1977).

64. - - - Vaiskonpalo. x 7515.02, y 497.18.

65. - $-\gg-$, Moskuvaara. x 7501.74, y 495.28 (Papunen 1977).

66. $\quad-\gg-\quad$, Vanttion Kotavaara. x 7502.58, y 485.25 .

quent glassy material which has shown to be rich in aluminium in the komatiitic rocks (Nisbet et al. 1977).

The limiting $\mathrm{MgO}$ content distinguishing the (basaltic)komatiites and komatiites is roughly estimated at 28-30 wt. \% (anhydrous basis). In spite of varying susceptibility to serpentinization the mineral compositions do not change sufficiently between the peridotitic and serpentinitic lavas to show systematic chemical differences in the komatiite flows (Tables 5-6).

\section{Paleotectonic position}

The Sattasvaara komatiite complex is upfacing and flatlying, containing some signs of crustal evolution, like volcanic conduits in

linear arrangement (Fig. 29), but any paleotectonic evaluation of the area is necessarily somewhat conjectural.

The cinder cone at Sattasvaara continues a line of other komatiitic vents, which is considered as a significant paleotectonic fault in northwest direction running from eastern SovietKarelia to central Lapland (Saverikko et al. 1985). Although superficial evidence of this connection is not strong, a scarp of the basement complex, gravimetrically established by E. Lanne, joins to this fault and is continuous from Sattasvaara to the northwest (Kallio 1980). Geophysical sounding indicates that the southwest block has subsided about $3 \mathrm{~km}$ relative to the opposite block (Lanne 1979). The Oraniemi rock suite (Fig. 3) on the subsided block shows also the range of the vertical move- 
ments what may imply that the main displacements took place before the komatiitic volcanism.

The Sattasvaara vent also links up with a fault in west-northeast direction delineated by the mafic volcanic neck and the isolated komatiitic lava pile in the form of a proximal deposit far away from the above-mentioned conduits. In addition, the ophite dikes or sheets, a few komatiite flows associated with a small neck, and the distinct pyroclastic deposit of komatiitic basalt are located in this fault zone. Signs of subsidence of the south block are the volcanic
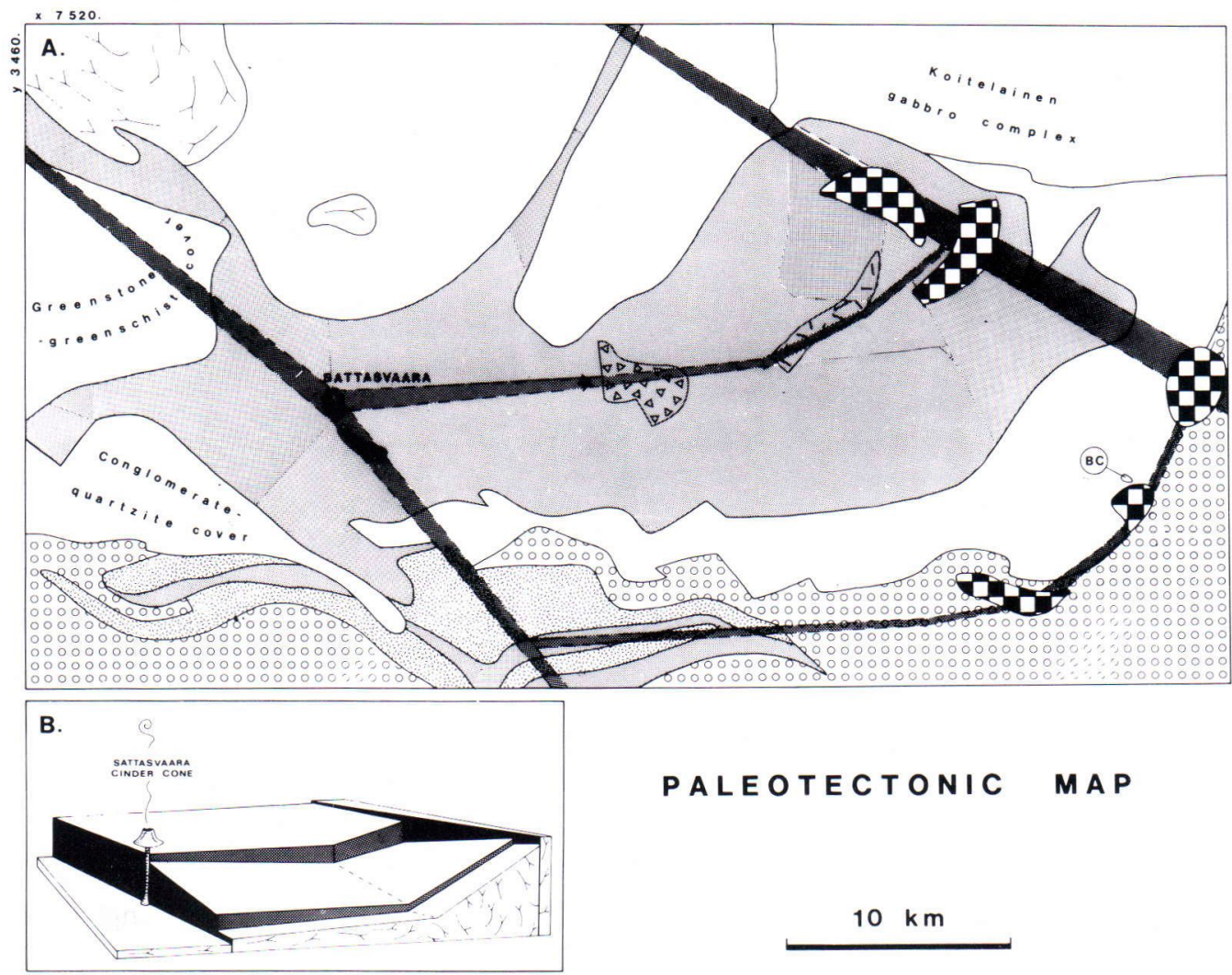

PALEOTECTONIC MAP

Graphitic slate zone and komatiite complex

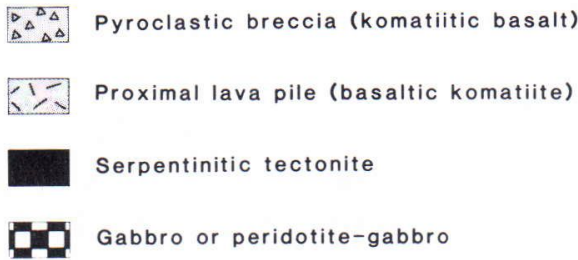

Amphibolite

$10 \mathrm{~km}$

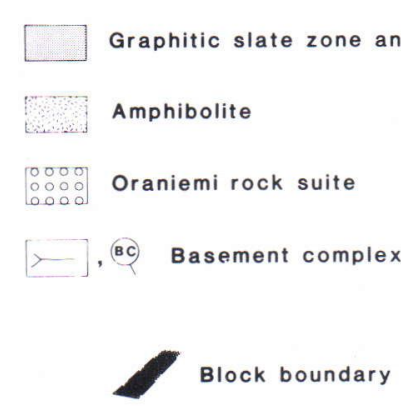

Fig. 29. Paleotectonic map of the Sattasvaara komatiite complex (A) and schematic block diagram (B) based on the thicknesses of the supracrustal rock units. The inaccurate term »serpentinitic tectonite» means a picrite plug emplaced perhaps under tectonic control. 
conglomerate blanket, pillowed komatiitic basalt lavas as a proof of submergence, and the thicker, largely greywacky, graphitic slate zone (Papunen et al. 1977), on the block. The movements must therefore have taken place during the deposition of the graphitic debris and discharge of the komatiitic lavas. The graphitic slate zone appears to be thickened eastwards suggesting an inclination of the southern block during its subsidence. If the Koitelainen gabbro complex, present as a laccolithic sheet slightly inclined towards the east, was emplaced through a fracture over $20 \mathrm{~km}$ long in northeast direction (Puustinen 1977), the fault might join to this fracture.

The inferred block boundary in northwest direction lying tangentially to the Koitelainen gabbro complex approximates the fault zone established by Aarnisalo (1978) as a fundamental fracture in nearby basement-complex areas and is reflected in the gabbro plugs disposed in linear arrangement in the supracrustal cover crossing the fault zone (Mattila 1974, Saverikko 1978). The graphitic slate zone, at least as electrical conductor, displays abruption to this fault zone.

A probable paleotectonic fault in northeast direction is defined only on the basis of a line of three gabbro plugs and of the strike of the amphibolite joining to the border of the Oraniemi rock suite. If the fault was substantial, it might explain the slump folds in the early Lapponian quartzite and the polymictic conglomerate in the metapelite (Saverikko 1978) alongside this line.

The existence of two significant parallel fault in northwest direction, associated with subsidence of the southwest blocks indicates rifting. Tectonic steps that are formed by the faults in northeast direction may represent a border zone of a possible aulacogen crossing the rift or half-rift. Their intersection point appears to have located the main visible komatiitic conduit at Sattasvaara.

\section{Paleogeographic environment}

The sedimentation in the down-faulted or faulting basin was dominantly euxinic-exhalative in origin judging from the excess of graphitic slate, sulphide slate, calc-silicatic and cherty rocks in the developed sedimentary pile. The thin stratification implies stagnant sedimentation conditions. The prevailing quiet sedimentation gave way to high-velocity deposition actually connected with faulting, and greywacke and minor conglomerate were deposited mixing with graphitic sediments.

In the restricted basin, volcanism of strongly varying character took place; felsic and mafic eruptions generated lavas and ejecta, and ultramafic volcanism produced komatiite lavas in three distinct phases. At least komatiitic eruptions were most probably connected with the faulting in northeast direction.

The block movements continued during numerous eruptions of which products have made up the Sattasvaara komatiite complex. The eruption phases with emission of komatiitic basalts discharged massive, smooth lava flows - pahoehoe flows - which are formed in subaerial environment (Macdonald 1972, p. 68 ), but the lava flows on submerged blocks were pillowed. In the largely subaerial complex there were also water-laid deposits of volcanic siltstone and epiclastic volcanic conglomerate.

Erosional periods occurred between the main komatiitic phases, as manifested by the epiclastic volcanic conglomerate and weathering breccia associated with volcanic conglomerate. During these intervals the komatiite complex has disintegrated and detritus been laid down into an adjoining southwest sedimentary basin, mixing with euxinic-exhalative sediments. In consequence of sufficiently fast transport the detritus does not show significant decomposition to aluminious sediment and according to voluminous terrigenous sedimentation the carbonaceous greenschists were formed rather than graphite slates. The basin, or the block under- 
neath, must have subsided during this sedimentary phase, because facies distribution in the nearby iron formations at Porkonen and Pahtavaara is vertical, changing from oxide at the bottom to sulphide at the top (Paakkola 1971). Tectonic activity accelerated the deposition at the end of this period: in addition to greywacke accumulated in 1-m-thick beds at the top of the greenschist pile (Räsänen 1977) there was deposited volcanic conglomerate blanket beside fault scarps, with paraconglomeratic lobes or lenses dispersed upon the carbonaceous greenschists at greater distance from the shore of the depositional basin.

The final eruption phase brought about (basaltic)komatiite ejecta and minor lava flows also upon the carbonaceous greenschists. This explosive eruption phase began with accumulation of the volcanic conglomerate mentioned above. First extrusions discharged also minor lavas in subaerial environment, under which conditions block lavas are formed (Macdonald 1972, p. 68); lava pillows are quite the exception. The explosive eruptions may have been voluminous and subaerial, what is indicated by predominant pyroclastics with crude or absent sorting of ejecta (Macdonald 1972, p. 135).

The komatiitic volcanism gave way to the mafic volcanism. The eruptions can have been partially simultaneous, but basalts discharged also through volcanic conduits that feeded the uppermost (basaltic)komatiite layer (see p. 82).

On the basis of the evolutionary evidences cited above the Sattasvaara komatiite complex appears originally to have been located at the margin of a restricted depositional basin formed in connection with rifting. The complex overlies and adjoins (ortho)quartzite-carbonate-schist association that is widespread in the lower part of the Lapponian supracrustal sequence (Mikkola 1941), and typical of cratonic sedimentation (Pettijohn 1975, p. 573). The Sattasvaara complex can therefore be thought to have formed on the shore of an intracratonic basin around which other komatiite volcanoes (Saverikko 1983) were situated, too.

\section{Paleovolcanism}

The Sattasvaara complex consists mainly of komatiitic basalts and to a lesser extent of (basaltic)komatiites, which have piled up in successive eruptions with or without recognizable interval. They are petrographically gradual and the ultrabasicity increases upward in the pile with propagated eruptions so that, along the final (basaltic)komatiite ejecta chemically closely similar to the komatiite, the terminal lava flows are komatiites provided with the thin (basaltic) komatiite crust. These all may be evidence of co-magmatic origin of the rocks. The genetic relation of the komatiites beneath the Sattasvaara complex to the rocks in the complex is obscure but their close association in space and time, not only at the Sattasvaara area but elsewhere (Kröner et al. 1981, Henriksen 1983, Saverikko 1983), suggests that they also originated from the same magma. In that case the komatiites would be the densely differentiated substance of this magma, as is suggested by the completely(?) cumulus-textured rocks.

The komatiitic basalt contains felsic ocelli, which are common in rocks of this komatiitic subsuite and are considered by some authors, in some cases, as evidence of liquid immiscibility (see Arndt et al. 1979 for references). Paakkola (1971) suggests the liquid immiscibility of silicate melts to explain the presence of the ultramafic extrusives among the greenstones in Lapland.

The komatiitic basalt predominating in the Sattasvaara complex was discharged in three distinct phases, of which the first was the initial phase in the evolution of the complex. The evolution terminated with the main explosive eruption phase producing (basaltic)komatiite.

The first eruption phase with komatiitic basalt lavas was succeeded by extrusions of 
(basaltic)komatiite, of poorly known origin, depositing lava flows and ejecta in a relatively thin succession. The two later eruption phases were successive, separated by an erosional period with few explosive eruptions; minor pyroclastic breccias were laid down. From the location of the pyroclastics upon pillow lavas and their association with water-deposited volcanic siltstone and epiclastic volcanic conglomerate it may be conjectured that these eruptions were hydromagmatic in origin. If the fragments in the conglomerate are actually redeposited pyroclasts, the laying down of the conglomerate does not necessarily imply a significant break in the effusion of the komatiitic basalt. The 3-mthick beds separated by depositional unconformities in the volcanic siltstone, and lying immediately beneath the next pillow lavas imply high-velocity currents activated most probably by earthquakes connected with the just commencing effusions.

The terminal eruption phase ejecting (basaltic)komatiite took place actually in the subaerial environment but several lava pillows beside the flow-top breccia at Sattasvaara may indicate a shoreline running near the cinder cone. This would provide the possibility of hydromagmatic effects to succeeding explosive eruptions but the absence of characteristics of Surtseyan eruptions (Walker 1973), and the considerable quantity of crystal ash in fine ejecta, after Heiken (1974), rather point to magmatic explosions. Phreatomagmatic effects may also have been insignificant according to the distinct association of pyroclasticity with the (basaltic) komatiites, both in the upper and lower layers, although the komatiitic basalts as well have erupted through the same underlying strata.

The ejecta are lithic-vitric and contain minor crystal ash that has usually been dispersed but also accumulated at least into one crystal-tuff deposit beside the cinder cone. The essential ejecta are accompanied by accessory ejecta that are visible f. ex. as cored lapilli. Extraordinary accidental ejecta are rare; the haematite-magne- tite lapilli may have been derived from iron formations lying within the carbonaceous slates (Lehto and Niiniskorpi 1977) beneath the komatiitic rocks rather than from ordinary haematitemagnetite lava. The existence of such lavas is nevertheless possible (Park 1961).

The iron formations at Porkonen and Pahtavaara are regarded as generated from the same volcanism that produced the amphibole-epidotechlorite rock, amphibole-epidote rock and amphibole-chlorite rock in their vicinity (Paakkola 1971). These rocks are petrographically similar to the komatiitic basalts and (basaltic) komatiites in the Sattasvaara complex. Iron formations elsewhere in Lapland also appear to have been connected with ultramafic volcanism in the same komatiite zone (Wennervirta 1969, Henriksen 1983, Saverikko 1983, 1984).

The main visible volcanic conduit of the komatiite complex is the cinder cone at Sattasvaara presently appearing as steep-sided perfectly exposed hill. The cored lapilli or lapilli with chilled margin or both occur mostly in and around the relict cone in which the ejecta appear to have squeezed and welded together. In addition, two lavas with recognizable flow direction seem to have poured out from the vent covered later by the cinder cone and one of them is penetrated by a lateral vent beside the Sattasvaara hill. Basaltic eruption fissures in the form of three greenstone dikes cutting the cone, and one greenstone neck nearby indicate that basaltic magma discharged also through this conduit after the komatiitic eruptions.

The large amounts of ejecta, minor block lavas and cinder cone found in the (basaltic) komatiite are characteristic of Stromboliantype eruptions; and the pahoehoe flows with sparse ejecta formed by the komatiitic basalt are indicative of Hawaiian-type eruptions (Macdonald 1972, pp. 213-221). The type of eruption depends largely on viscosity of the magma: for example, blocky flows are supposed to be formed from a more viscous lava than pahoehoe flows (Macdonald 1953) and highly viscous 
magma generally forms glassy pyroclasts (Fisher and Schmincke 1984, p. 76) that are very common in the (basaltic)komatiite ejecta. The high viscosity of the (basaltic)komatiite lava also explains the appreciable amounts of pyroclastics in the amphibole-chlorite rock.

The komatiites appear to have originated from fluid lava that formed extensive thin flow piles after the manner of flood eruptions. But the terminal flows with thin blocky crust of (basaltic)komatiite composition, in the Sattasvaara complex, may have originated from viscous lava.

Although pyroclastics are exceptional in the komatiitic rock suites encountered in the world (Arndt et al. 1979), in the Baltic Shield these rocks have made up an extensive arc-shaped zone (Saverikko et al. 1985). In other words, the high viscosity of (basaltic)komatiite is a unique phenomenon, departing as it does so widely from the physical conditions prevailing in the komatiitic lavas (Nisbet 1982).

\section{Conclusions}

The Sattasvaara komatiite complex lies in upper part of the Lapponian supracrustal sequence in which the lower part is in large areas characterized by cratonic (ortho)quartzite-carbonate-schist association. Komatiitic volcanism at Sattasvaara took place later than $2.7 \mathrm{Ga}$ ago but before the emplacement of the Koitelainen gabbro ( $2.43 \mathrm{Ga}$ in age) that includes komatiitic xenoliths and has effected contact-metamorphic changes in the nearby komatiites. The Sattasvaara complex and other komatiitic volcanoes at the margin of intracratonic depositional basin have formed an extensive arc-shaped zone of pyroclastic komatiites. A large-scale fault in northwest direction, showing vertical displacement of $3 \mathrm{~km}$ magnitude as riftal evidence has controlled the volcanism; main visible komatiitic conduit appears to have been located at intersection point of a possible aulacogen.
The Sattasvaara komatiite complex $(h>1.7$ $\mathrm{km}$ ) is composed of three amphibole rock layers and amphibole-chlorite rock present in one interlayer and the uppermost layer. The amphibole rock, or komatiitic basalt ( $\mathrm{MgO} 9-18$ wt.\% anhydrous basis), and the amphibole-chlorite rock, or (basaltic)komatiite (MgO 18-29 wt.\% anhydrous basis), appear to be co-magmatic, forming a transitional rock suite. The (basaltic)komatiite grades in final eruption products into komatiite $(\mathrm{MgO}>29$ wt.\% anhydrous basis), what is present $f$. ex. in the form of a few serpentinitic or peridotitic lava flows covered with thin crust of amphibole-chlorite rock. However, most komatiites have discharged before the formation of the Sattasvaara complex; the flow piles intercalated within graphitic slates have previously been regarded as peridotite sills.

Main petrologic difference between the komatiitic derivative magmas appears in degree and products of fractional crystallization. The komatiitic basalt shows relic phenocrysts of pyroxene and plagioclase; chemical composition of the (basaltic)komatiite is indicative of a significant amount of original pyroxene and some olivine, and the pyroxene seems to be augite and diopside; the accumulative komatiites are rich in olivine in various degree, containing also original augite and hyperstene.

On the basis of petrographic and stratigraphic features in the complex, the komatiitic magma has discharged in slightly rythmic manner with increasing ultrabasicity connected with propagated eruptions. Weathering breccia and epiclastic and volcanic conglomerates indicate that erosional periods occured between the eruption phases.

The komatiitic basalt is present usually in massive flows but upon submerged fault blocks the flows are pillow lavas. Presence of small spatter cones associated with the pahoehoe flows is possible. Several pyroclastic breccias have extruded and stratified in subaqueous environment and, therefore, have thought to be 
hydromagmatic in origin.

The (basaltic)komatiite is predominantly pyroclastic, and subordinate lavas at least in the uppermost layer are mostly block lavas. The block lavas and extensive pyroclastic deposits with crude or absent sorting of ejecta may be evidence of subaerial environment, although the cinder cone at Sattasvaara has been located near a shoreline. Explosive eruptions are regarded as magmatic in origin, because crystal tuff appears also in considerable amount in fine fraction of the lithic-vitric ejecta. Possible hydromagmatic or phreatomagmatic eruptions have not effected in significant degree.

As a unique phenomenon, the (basaltic) komatiite magma has been highly viscous, producing dominantly pyroclastics with frequent glassy ejecta and minor lavas in the form of blocky flows rather than pahoehoe flows. These all and the cinder cone are characteristics of Strombolian-type eruptions. The komatiitic basalt present in the pahoehoe flows and sparse ejecta has erupted in Hawaiian type, whereas the komatiite magma, except in the terminal lavas in the complex, may have been most fluidal and the relatively thin and extensive flows have discharged in the manner of flood eruptions.

General explorational features are also mentioned briefly. The komatiitic basalt contains a stratiform horizon of carbonate-chlorite-talc rock, what kind of rock in the same stratigraphic level is associated with gold-bearing chromian marbles outside the area investigated. Native gold $(1.5-5 \mathrm{ppm})$ occurs also in the local relic

\section{References}

Aarnisalo, Jussi, 1978. Use of satellite pictures for determining major shield fractures relevant for ore prospecting, northern Finland. Geol. Surv. Finland Rep. Invest. 21.

Arndt, Nicholas \& Brooks, Cristopher, 1980. Komatiites. Penrose Conference Report. Geology 8, 155-156. of the Kumpu rock suite, overlying the Sattasvaara komatiite complex and has been disintegrated from sulphide-quartz veins cutting the komatiitic rocks (Härkönen 1983). In addition, some jaspilitic iron ores in Finnish and Norwegian Lapland have been connected with komatiitic volcanism. The manganoferrous iron ores at Porkonen and Pahtavaara, just outside the study area, are associated with carbonaceous greenschists that have laid down immediately before the final komatiitic eruption phase.

Note addes in proof. - The ultramafic volcanics should be called cumulate and noncumulate komatiites instead of the komatiites and (basaltic)komatiites, respectively.

Acknowledgements. This investigation was aided financially by grants from the Academy of Finland (project 24/001; Leader, Dr. T. Koljonen) and from the Outokumpu Oy Foundation.

I wish to record my gratitude to Prof. I. Haapala of the University of Helsinki and to the Follow-up Group of the project: Profs. N. Edelman, I. Haapala, J. Nuutilainen, J. Kankare and J. Siivola. All of these persons actively supported my work with fruitful advice. Thanks are due as to Mr. R. Hugg of the Exploration Department of Rautaruukki Oy, Messrs. K. Airas and O. Inkinen, of Lapin Malmi and Mr. A. Tyrväinen of the Geological Survey of Finland for geological material put at my disposal.

Prof. N. T. Arndt of the Max-Planck-Institut für Chemie, in Mainz, and Dr. K. Kinnunen of the Geological Survey of Finland have kindly read the manuscript and given many critical comments.

I dedicate this work to the memory of my father who passed away some days before this manuscript was submitted.

-, Nicholas, T., Francis, Donald \& Hynes, Andrew J., 1979. The field characteristics and petrology of Archean and Proterozoic komatiites. Can. Mineral. 17, 147-169.

-, N. T. \& Nisbet, E. G., 1982. What is komatiite? In: Arndt, N. T. and Nisbet, E. G. (Editors) Komatiites. George Allen \& Unwin. London. 19-27.

Auvray, B.; Blais, S.; Jahn, B.-M. \& Piquet, D., 1982. Komatiites and the komatiitic series of the Finnish green- 
stone belts. In: Arndt, N. T. and Nisbet, E. G. (Editors) Komatiites. George Allen \& Unwin. London. 131-146.

Blais, S.; Auvray, B.; Cardevila, R.; Jahn, B. M.; Bertrand, J. M. \& Hameurt, J., 1979. The Archaean greenstone belts of Karelia (eastern Finland) and their komatiitic and tholeiitic series. In: Windley, B. and Naqvi, S. M. (Editors) Developments in Precambrian Geology, I. Archaean Geochemistry. Elsevier. Amsterdam-OxfordNew York. 87-107.

Cook, E. F., 1965. Stratigraphy of Tertiary volcanic rocks in eastern Nevada. Nev. Bur. Mines Rep. 11. (referred to in Heiken 1974).

Fisher, Richard V., 1961. Proposed classification of volcanoclastic sediments and rocks. Geol. Soc. Am. Bull. 72, 1409-1414.

-, 1966. Rocks composed of volcanic fragments and their classification. Earth-Sci. Rev. 1, 287-298.

- \& Schmincke, H.-U., 1984. Pyroclastic Rocks. SpringerVerlag, Berlin-Heidelberg-New York-Tokyo.

Gaál, Gabor; Mikkola, Aimo \& Söderholm, Bengt, 1978. Evolution of the Archean crust in Finland. Precambrian Res. 6, 199-215.

Gehör, Seppo, 1982. Kittilän manganosideriittiliuskeiden petrografia, mineralogia ja geokemia. M. Sci. Thesis, Dept. Geol. Univ. Oulu.

Haimi, Marianne, 1977. Luoston alueen geologia. M. Sci. Thesis, Dept. Geol. Univ. Helsinki.

Hanski, Eero, 1980. Komatiitic and tholeiitic metavolcanics of the Siivikkovaara area in the Archean Kuhmo greenstone belt, eastern Finland. Bull. Geol. Soc. Finland 52, 1, 67-100.

Härkönen, Ilkka, 1983. The gold-bearing conglomerates of Kaarestunturi, central Finnish Lapland. In: Foster, R. P. (Editor) Gold'82: The Geology, Geochemistry and Genesis of Gold Deposits. A. A. Balkema, Rotterdam. $239-247$.

Heiken, Grant, 1974. An atlas of volcanic ash. Smithsonian Contrib. Earth Sci. 12.

Henriksen, Helge, 1983. Komatiitic chlorite-amphibole rocks and mafic metavolcanics from the Karasjok greenstone belt, Finnmark, northern Norway: A preliminary report. Nor. Geol. Unders. 382, 17-43.

Hörmann, Paul Karl; Raith, Michael; Raase, Peter; Ackermand, Dietrich \& Seifert, Friedrich, 1980. The granulite complex of Finnish Lapland: petrology and metamorphic conditions in the Ivalojoki-Inarijärvi area. Geol. Surv. Finland Bull. 308.

Isomaa, Jorma, 1978. Lapin liuskemuodostuma Petkulan alueella Sodankylän pohjoispuolella. M. Sci. Thesis, Dept. Geol. Univ. Oulu.

Jensen, L. S., 1976. A new method of classifying subalkalic volcanic rocks. Ontario Div. Min. Misc. Paper 66. (referred to in Jensen and Pyke 1982).

Jensen, L. S. \& Pyke, D. R., 1982. Komatiites in the On- tario portion of the Abitibi belt. In: Arndt, N. T. and Nisbet, E. G. (Editors) Komatiites. George Allen \& Unwin. London. 147-157.

Kallio, Mauri, 1980. Keski-Lapin liuske alue Itä-Kittilän ja Länsi-Sodankylän osalta, osa II: rakenne ja stratigrafia. M. Sci. Thesis, Dept. Geol. Univ. Oulu.

—, Kärkkäinen, Niilo \& Sarapää, Olli, 1980. Keski-Lapin liuskealue Itä-Kittilän ja Länsi-Sodankylän osalta, osa I: petrografinen kuvaus ja kallioperäkartta. M. Sci. Thesis, Dept. Geol. Univ. Oulu.

Kröner, A.; Puustinen, K. \& Hickman, M., 1981. Geochronology of an Archaean tonalitic gneiss dome in northern Finland and its relation with an unusual overlying volcanic conglomerate and komatiitic greenstone. Contrib. Mineral. Petrol. 76, 33-41.

Lanne, Erkki, 1979. Vuotoksen ja Kittilän alueiden geofysikaalisten tietojen tulkinnasta. Summary: On the interpretation of geophysical data from the Vuotos and Kittilä areas, northern Finland. Geol. Surv. Finland Rep. Invest. 25.

Lehto, Tapio \& Niiniskorpi, Veikko, 1977. Pohjois- ja ItäSuomen rautamuodostumat. Summary: The iron-formations of northern and eastern Finland. Geol. Surv. Finland Rep. Invest. 22.

Macdonald, Gordon A., 1953. Pahoehoe, aa, and block lava. Am. J. Sci. 251, 169-191.

-, 1972. Volcanoes. Prentice- Hall, Inc. Englewood Cliffs. New Jersey.

Mattila, Hannu, 1974. Karelidit Savukosken Tanhuan alueella, Keski-Lapissa. M. Sci. Thesis, Dept. Geol. Univ. Oulu.

Meriläinen, Kauko, 1976. The granulite complex and adjacent rocks in Lapland, northern Finland. Geol. Surv. Finland Bull. 281.

-, 1980. On the stratigraphy of the Karelian formations. In: Silvennoinen, A. (Editor) Jatulian Geology in the Eastern Part of the Baltic Shield. Proceedings of a Finnish-Soviet Symposium held in Finland, 21st-26th August, 1979. The Committee for Scientific and Technical Co-operation between Finland and Soviet Union. Rovaniemi 1980. 97-112.

Mielikäinen, Pekka, 1979. Geological Map of Finland. PreQuaternary Rocks. Sheet 3642-Pelkosenniemi. 1:100 000. Geol. Surv. Finland, Espoo.

Mikkola, Erkki, 1941. Suomen geologinen yleiskartta. Kivilajikartan selitys. Lehdet-Sheets B7-C7-D7 MuonioSodankylä-Tuntsajoki. General Geological Map of Finland. Summary: Explanation to the Map of Rocks. Geol. Comm. Finland, Helsinki [Now: Geol. Surv. Finland, Espoo].

Mutanen, Tapani, 1976. Komatiites and komatiite provinces in Finland. Geologi 28, 49-56.

Nisbet, E. G., 1982. The tectonic setting and petrogenesis of komatiites. In: Arndt, N. T. and Nisbet, E. G. (Editors) 
Komatiites. George Allen \& Unwin. London. 501-520.

—, Euan G.; Bickle, M. J. \& Martin, A., 1977. The mafic and ultramafic lavas of the Belingwe greenstone belt, Rhodesia. J. Petrol. 18, 4, 521-566.

Paakkola, Juhani, 1971. The volcanic complex and associated manganiferous iron formation of the PorkonenPahtavaara area in Finnish Lapland. Bull. Comm. Géol. Finlande [Now: Geol. Surv. Finland Bull.] 247.

Papunen, H. (Editor) 1977. Lapin ultramafiittien geologiset, petrologiset, geokemialliset ja mineralogiset tiedot. Lapin nikkeliprojektin dokumenttikokoelma. Archives of Geol. Surv. Finland, Espoo.

—, Heikki; Häkli, T. A.\& Idman, Hannu, 1979. Geological geochemical and mineralogical features of sulfide-bearing ultramafic rocks in Finland. Can. Mineral. 17, 217-232.

-, H.; Idman, H.; Ilvonen, E.; Neuvonen, K. J.; Pihlaja, P. \& Talvitie, J., 1977. Lapin ultramafiiteista. Summary: The ultramafics of Lapland. Geol. Surv. Finland Rep. Invest 23.

Park, Charles F., Jr., 1961. A magnetite »flow» in northern Chile. Econ. Geol. 56, 431-441.

Pearton, T. N., 1982. Gold and antimony mineralization in altered komatiites of the Murchison greenstone belt, South Africa. In: Arndt, N. T. and Nisbet, E. U. (Editors) Komatiites. George Allen \& Unwin. London. 459-475.

Pekkala, Yrjö \& Puustinen, Kauko, 1978. The chromian marbles of Kittilä, Finnish Lapland. Bull. Geol. Soc. Finland 50, 1-2, 15-30.

Pettijohn, E. J., 1975. Sedimentary Rocks. 3rd Edition. Harper \& Row, Publishers. New York, Evanston, San Francisco and London.

Pulkkinen, E.; Rahkola, P. \& Saverikko, M., 1983. Case study of a geochemical anomaly in a komatiite area in northern Finland. In: Björklund, A. and Koljonen, T. (Editors) Abstracts. 10th IGES - 3rd SMGP, August 29 to September 2, 1983, Espoo/Helsinki. 64.

Puustinen, K., 1977. Exploration in the northeast region of the Koitelainen gabbro complex, Sodankylä, Finnish Lapland. In: Davis, G. R. (Editor) Prospecting in Areas of Glaciated Terrain. Inst. Min. Met. London. 6-13.

Räsänen, Jorma, 1977. Kaarestunturi-muodostuma ja sen sijainti Keski-Lapin liuskejaksossa. M. Sci. Thesis, Dept. Geol. Univ. Helsinki.

-, 1984. On the Archean and Proterozoic komatiites in the Savukoski area, NE-Finland. In: Armands, G. and Schager, S. (Editors) Abstracts. 16e Nordiska Geologiska Vintermötet, 9-13 januari 1984, Stockholm. 189.

Rask, Markku, 1978. Kivilajeista ja metapeliittien progressiivisesta metamorfoosista Sodankylän Kelujärven alueella Keski-Lapissa. M. Sci. Thesis, Dept. Geol. Univ. Helsinki.

Rastas, P., 1980. Stratigraphy of the Kittilä area. In: Silven- noinen, A. (Editor) Jatulian Geology in the Eastern Part of the Baltic Shield. Proceedings of a Finnish-Soviet Symposium held in Finland 21st-26th August 1979. The Committee for Scientific and Technical Cooperation between Finland and the Soviet Union. Rovaniemi 1980. 145-152.

Sahama, Th. G., 1945. Spurenelemente der Gesteine im südlichen Finnish = Lapland. Bull. Comm. Géol. Finlande [Now: Geol. Surv. Finland Bull.] 135.

Sarapää, Olli, 1980. Keski-Lapin liuskealue Itä-Kittilän ja Länsi-Sodankylän osalta, osa III: vulkaniittien geokemia. M. Sci. Thesis, Dept. Geol. Univ. Oulu.

Saverikko, Matti, 1977. Oraniemen liuskeiden kerrostumisjärjestys ja stratigrafinen sijainti Keski-Lapin liuskejaksossa. M. Sci. Thesis. Dept. Geol. Univ. Helsinki.

-, 1978. Keski-Lapin liuskejakson stratigrafian, sedimentaation ja rakenteen pääpiirteet Sodankylän, Savukosken ja Pelkosenniemen alueella. Res. Rap. 6/78 (unpublished), Dept. Explor. Rautaruukki Oy, Oulu.

—, 1983. The Kummitsoiva komatiite complex and its satellites in northern Finland. Bull. Geol. Soc. Finland 55, 2, $111-139$.

-, 1984. Comment on relation of banded iron formations to basaltic komatiites at Kummitsoiva in northern Finland. Geologi 36, 84-86.

—; Koljonen, Tapio \& Hoffrén, Väinö, 1985. Paleogeography and paleovolcanism of the Kummitsoiva komatiite complex in northern Finland. In: Laajoki, K. and Paakkola, J. (Editors) Proterozoic exogenic processes and related metallogeny. Geol. Surv. Finland Bull., 331, 143-158.

— \& Manninen, Tuomo, 1981. Keminniemi/Saijan osaalueen kivilajit, stratigrafia, rakenteet ja malmikriittiset vyöhykkeet. Res. Rap. 8/81 (unpublished), Dept. Explor. Rautaruukki Oy, Oulu.

Sederholm, J. J., 1932. On the geology of Fennoscandia with special reference to the pre-Cambrian. Bull. Comm. Geol. Finlande 98.

Silvennoinen, A.; Honkamo, M.; Juopperi, H.; Lehtonen, M.; Mielikäinen, P.; Perttunen, V.; Räsänen, J. \& Väänänen, J., 1980. Main features of the stratigraphy of North Finland. In: Silvennoinen, A. (Editor) Jatulian Geology in the Eastern Part of the Baltic Shield. Proceedings of a Finnish - Soviet Symposium held in Finland, 21st-26th August, 1979. The Committee for Scientific and Technical Co-operation between Finland and Soviet Union. Rovaniemi 1980. 153-162.

Simonen, Ahti, 1960. Pre-Quaternary rocks in Finland. Bull. Comm. Geol. Finlande 191.

-, 1971. Das finnische Grundgebirge. Geol. Rundsch. 60, 4, 1406-1421.

-, 1980. The Precambrian in Finland. Geol. Surv. Finland Bull. 304.

Taipale, Kalle, 1983. The geology and geochemistry of the 
Archean Kuhmo greenstone-granite terrain, in the Tipasjärvi area, eastern Finland. Acta Univ. Ouluensis. Sci. Rerum. Nat. 151.

Tyrväinen, Aimo, 1979. Geological Map of Finland. PreQuaternary Rocks. Sheet 3713-Sodankylä. 1 : 100000. Geol. Surv. Finland, Espoo.

—, 1983. Sodankylän ja Sattasen kartta-alueiden kallioperä. Kallioperäkarttojen selitykset. Lehdet-Sheets 3713 and 3714. Summary: Pre-Quaternary rocks of the Sodankylä and Sattanen map-sheet areas. Geol. Surv. Finland, Espoo.

Viljoen, M. J. \& Viljoen, R. P., 1969. The geology and geochemistry of the lower ultramafic unit of the Onverwacht Group and a proposed new class of igneous rock.
Sp. Publ. Geol. Soc. S. Afr. 2, 221-244.

-; Viljoen, R. P. \& Pearton, T. N., 1982. The nature and distribution of Archaean komatiite volcanics in South Africa. In: Arndt, N. T. and Nisbet, E. G. (Editors) Komatiites. George Allen \& Unwin. London. 53-79.

Wennervirta, Heikki, 1969. Karasjokområdets geologi. English summary. Nor. Geol. Unders. 258.

Walker, George P. L., 1973. Explosive volcanic eruptions a new classification scheme. Geol. Rundsch. 62, 2, 431-446.

Williams, D. A. C., 1971. Determination of primary mineralogy and textures in ultramafic rocks from Mt Monger, western Australia. Spec. Publs. Geol. Soc. Aust. 3, $259-268$. 